
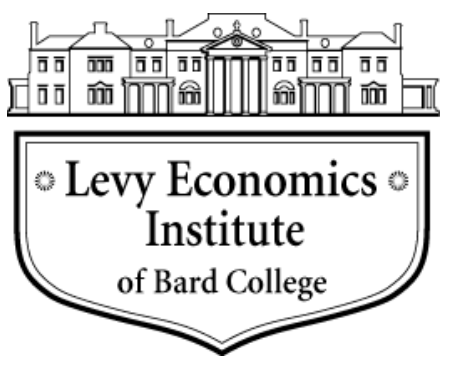

Working Paper No. 941

\title{
Wage Differential between Palestinian Non-refugees and Palestinian Refugees in the West Bank and Gaza
}

\author{
by \\ Sameh Hallaq \\ Levy Institute and \\ Al-Quds Bard College for Arts and Sciences
}

December 2019

The Levy Economics Institute Working Paper Collection presents research in progress by Levy Institute scholars and conference participants. The purpose of the series is to disseminate ideas to and elicit comments from academics and professionals.

Levy Economics Institute of Bard College, founded in 1986, is a nonprofit, nonpartisan, independently funded research organization devoted to public service. Through scholarship and economic research it generates viable, effective public policy responses to important economic problems that profoundly affect the quality of life in the United States and abroad.

Levy Economics Institute

P.O. Box 5000

Annandale-on-Hudson, NY 12504-5000

http://www.levyinstitute.org

Copyright (C Levy Economics Institute 2019 All rights reserved

ISSN 1547-366X 


\begin{abstract}
This paper measures the wage differential between Palestinian non-refugees and Palestinian refugees in the West Bank and Gaza over the years 1999-2012. First, the main individual and occupational differences between the two groups in the two regions are presented. Then, the wage differential is decomposed into two components: a "human capital effect, explained part" and a "coefficient effect, unexplained part." Second, findings suggest that though the wage gap has always existed and favored non-refugees in the West Bank, it has a more substantial impact among low-skilled workers and those in the private sector. Furthermore, most of this gap is attributed to the unexplained part of the wage decomposition model. In Gaza, the wage gap favored refugee workers. Most of this wage gap among unskilled workers is attributed to the endowment/human capital effect, while for skilled workers most of the wage gap is due to the unexplained part— the "coefficient effect"—after 2006.
\end{abstract}

KEYWORDS: West Bank; Gaza Strip; Wage Differential; Refugees

JEL CLASSIFICATIONS: J31; J71 


\section{INTRODUCTION}

As a result of the 1948 war, thousands of Palestinians fled their homes and became refugees. Unlike the refugees in other parts of the world, Palestinian refugees who were forced to relocate to Palestinian territories, like the West Bank and Gaza Strip, led to consecutive generations of Palestinian refugees. Although they have the same nationality as their hosting communities, these Palestinian refugees are still suffering from different adverse life circumstances. This paper employs the Palestinian Labor Force Survey (PLFS) conducted by the Palestinian Central Bureau of Statistics (PCBS) to measures the wage differential between Palestinian nonrefugees and Palestinian refugees in the West Bank and Gaza over the years 1999-2012. It aims to indicate whether these differences in wages are attributed to the refugees' characteristics or attributed to the unexplained components of the wage decomposition model. Further, it discusses how this wage gap varies among skilled and unskilled workers in the Palestinian labor market.

Economists have pointed to various factors that may account for the main reasons behind the difference in earnings. They have also focused on labor market discrimination as a cause of the inequality among groups classified by gender, ethnicity, and other characteristics.

Discrimination against individuals hurts labor market outcomes, including job opportunities, promotions, and earnings - of which the level is hard to measure (Kaas and Manger 2012). Although controlling for educational and other socioeconomic characteristics among different groups could explain several individual wage differentials, part of this earning gap could not be explained. Therefore, it has been attributed to labor market discrimination (Altonji and Pierret 2001; Black et al. 2006). This paper focuses on the wage differential in the Palestinian labor market among refugees and non-refugees. According to the United Nations Relief and Works Agency for Palestine Refugees in the Near East (UNRWA), ${ }^{1}$ Palestinian refugees are defined as anyone whose "normal place of residence was Palestine during the period June 1, 1946 to May 15, 1948 and who lost both home and means of livelihood as a result of the 1948 conflict." This

\footnotetext{
${ }^{1}$ The United Nations Relief and Works Agency for Palestine Refugees in the Near East (UNRWA) was established in late 1949 following the 1948 Arab-Israeli conflict to carry out direct relief and works programs for Palestinian refugees.
} 
definition has expanded to include the children or grandchildren of such refugees, and they are eligible for agency assistance if they are registered with the UNRWA, living in the area of the UNRWA's operations, and in need (UNRWA 2017). ${ }^{2}$

Palestinian refugees represent 41.2 percent of the total Palestinian population living in Palestine. In general, the living conditions of Palestinian refugees are worse than those of non-Palestinian refugees. According to the monthly household real consumption patterns in Palestine, the poverty index among refugees reached 31.2 percent in 2011 compared with 21.8 percent for non-refugees. Furthermore, there is a clear difference in levels of unemployment among refugees and non-refugees in 2014 (33.7 percent versus 22.3 percent, respectively). It is also significant that the education level among Palestinian refugees is higher than that among nonrefugees, with a higher female labor force participation rate (PCBS 2015). ${ }^{3}$

The Palestinian labor market has experienced various structural changes, many of which are not to the advantage of its workers. First, the skilled labor force faced a decrease in the returns to schooling due to an increase in the educated labor supply after 1980 following an increase in the number of colleges and universities (Angrist 1995). Then, the economy was destroyed as a result of the outbreak of the First and Second Palestinian Intifada in the periods 1987-93 and 2000-5, respectively (Daoud 2005). A relatively small improvement occurred after the establishment of the Palestinian National Authority (PNA) in 1994 (MAS 2014). The restrictions on labor movements by the Israeli authorities led to significant adverse effects on Palestinian wages, with a sharp increase in unemployment (Mansour 2010; Miaari and Sauer 2011). Finally, since 2006, the PNA has experienced a reduction in the volume of financial aid, which represents the vast majority of the Palestinian budget (Sarsour, Naser, and Atallah 2011). The Palestinian labor market is characterized by an excess labor supply in relation to the

\footnotetext{
${ }^{2}$ Today, some five million Palestine refugees are eligible for services from UNRWA. Nearly one-third of the registered Palestine refugees (totaling more than 1.5 million individuals) live in 58 recognized Palestine refugee camps in Jordan, Lebanon, the Syrian Arab Republic, the Gaza Strip, and the West Bank, including East Jerusalem. For more details, see www.unrwa.org.

${ }^{3}$ According to the PCBS (2015), the percentage of Palestinian refugees aged 15 years and over who obtained a bachelor's degree or higher reached 13.7 percent of the total refugees against 11.6 percent for non-refugees, while the rate of female labor force participation for refugees living in Palestine reached 20.9 percent against 18.4 percent for non-refugees.
} 
demand, hence unemployment is high. The low female participation rate (Miaari 2009) and the high growth rate of public employment ${ }^{4}$ are due to weaknesses in the private sector in terms of absorbing the enormous increase in worker numbers; this is also a result of the restrictions on movements, investments, exports, and imports, as well as the high population growth (Daoud and Shanti 2016).

After a thorough search for relevant studies regarding the differences between Palestinian nonrefugees' and Palestinian refugees' wages, to the best of my knowledge, only two studies refer to that issue. Angrist (1998) employed labor force survey data collected by the Israel Central Bureau of Statistics for the period 1992-95 and suggested that the first and second generations ${ }^{5}$ of refugees earned less than non-refugees in both the West Bank and the Gaza Strip. He pointed to the fact that, after the establishment of the PNA in 1994, the gap for the second generation of refugees in the West Bank shrunk, and the overall pattern suggests that refugees' gaps have been closing. In the Gaza Strip, the second generation of refugees earned no less than other workers after 1992. Daoud (2005) found that refugees earned 3-4 percent less than non-refugees in 1999 and 2001, before and after the Second Palestinian Intifada.

The current paper takes these earlier works as a starting point and aims to make several contributions. First, it estimates the wage differential among Palestinian non-refugees and Palestinian refugees in the West Bank and Gaza Strip and describes its dynamics between 1999 and 2012. Second, it aims to discover how much of this wage gap can be explained by differences in individuals' characteristics and how much is due to the returns to these characteristics across the two population groups. Third, it discusses the impact of some individual wage determinant variables - such as gender, education, experience, seniority, working in Israel, and employment sector —on the observed wage gap between the two groups and the extent to which this observed gap varies between skilled and unskilled workers in the West Bank and Gaza.

\footnotetext{
${ }^{4}$ However, hiring in the public sector has recently been capped at only 3,000 per year (MAS 2014).

5 The first generation of refugees represents those Palestinians who resided in Israel in 1948, while the second generation of refugees represents those refugees whose fathers resided in Israel in 1948.
} 
The current study argues that the pattern in the wage differential in the West Bank is in favor of non-refugees during all the observation periods. This trend can be explained by a change in the relative prices of observed characteristics of non-refugee and refugee workers, as well as changes in the workers' characteristics. The greater effect, however, can be attributed to the workers' characteristics until 2005 (when the Second Intifada ended), while the unexplained part makes a larger contribution to explaining the wage gap after the Second Intifada. The wage gap has a larger significant impact on unskilled than skilled laborers and greater prevalence in the private sector. In the Gaza Strip, the wage gap is always in favor of refugee workers, and most of this gap is explained by workers' human capital components, or the "endowment effect."

The results of this paper have important policy implications regarding wage equity. The existence of wage inequality poses challenges for policymakers in terms of providing appropriate legislation that prevents wage discrimination. Furthermore, the Palestinian community is required (both by law and out of necessity) to invest in new resources to absorb the population growth, mainly since Palestinian refugees are often more educated and have higher fertility rates than their non-refugee Palestinian counterparts (PCBS 2015). The results also indicate the role of education in reducing the wage gap between Palestinian non-refugees and Palestinian refugees. Investment in education will also reduce the Palestinian labor market's dependency on employment in Israel, since the wages in the domestic labor market were negatively affected during the closure period ${ }^{6}$ by the increase in the labor supply (Daoud and Sadeq 2014; Mansour 2010; Miaari and Sauer 2011). Additionally, workers with low educational attainment earn higher salaries than educated laborers employed locally, leading to reduced economic returns to schooling.

The remainder of this paper is structured as follows. Section 2 presents the data used in this work and provides some descriptive statistics of the sample. It also documents the overall wage gap trend among Palestinian non-refugees and Palestinian refugees during the study period. Section 3 examines workers' characteristics and occupational differences during and after the

\footnotetext{
${ }^{6}$ Mobility is extremely difficult in the West Bank and Gaza Strip due to the imposed restrictions by the Israeli Authority, such as the checkpoints, closures, and the existence of the separation wall.
} 
Second Intifada. Section 4 provides the model and empirical analysis. The results are presented in section 5; section 6 shows the robustness checks, followed by the conclusion.

\section{DATA}

The current study employs the PLFS conducted by the PCBS on a quarterly basis over the years 1999-2012. Each household that participated in the PLFS was interviewed twice consecutively, left for two quarters, then interviewed again for two quarters. The sample is restricted to those who were wage employees, ages $15-65$, and classified within the labor force according to the PCBS. The refugee status was identified based on the respondent's answer regarding whether $\mathrm{s} /$ he is registered as a refugee. ${ }^{7}$ For the purpose of the analysis, the natural logarithm (LN) of workers' daily wages is used, which is calculated by dividing monthly income by the number of days worked per month. Table 1 reports the descriptive statistics of the main variables used in this paper. The registered refugees represent 48 percent of the total observations: 69 percent of the observations live in the West Bank and the remaining 31 percent live in the Gaza Strip. Despite the fact that refugees represent approximately half of the sample, only 19 percent of the total sample lives in camps. The majority of the sample is male, since the Palestinian labor market is characterized by a low female participation rate.

Figure 1 shows the wage differential trend between non-refugees and refugees in the Palestinian territories from 1999 to 2012. The unadjusted wage gap increased until 2000 and sharply decreased during the Second Intifada (2000-5). This gap continued to expand after the Second Intifada, except in 2009, when the wage gap was at its minimum level. However, this gap took a different direction when the sample was split between the West Bank and Gaza. The geographic and administrative segmentation between the two regions is very pronounced and poses a significant constraint on growth. Each operates with its own labor market characteristics, labor demand, and wage levels (MAS 2014). Gaza is facing more unstable economic conditions due to continuous border closures and higher unemployment rates. The overall conflict intensity in

\footnotetext{
${ }^{7}$ More than 1.7 million Palestinian refugees are not registered with the UNRWA (MIFTAH 2003). In the sample utilized, more than 92 percent of the refugees are registered with the UNRWA. Including both officially registered refugees and nonregistered refugees in the analysis does not change the results in the robustness check section.
} 
the Gaza Strip is higher than that in the West Bank due to the effect of three military operations in 2008-9, 2012, and 2014. Since 2007, Gaza has been governed by a different authority, and, most importantly, the percentage of the refugee population in Gaza is higher than the West Bank percentage. ${ }^{8}$ Figures $2 \mathrm{~A}$ and $2 \mathrm{~B}$ show the different patterns of wage distribution in the two regions. In the West Bank, the share of refugees receiving lower wages is higher than that of non-refugees; when the daily wage starts to increase, the percentage of non-refugees becomes higher than that of refugees. The vertical lines show that refugee workers have a lower mean unadjusted LN wage than non-refugee workers. In Gaza, the opposite case applies.

Next, looking at the wage gap over the years in the two regions, figure 3 depicts the trend and the different directions of the wage gap between the two population groups in the West Bank and the Gaza Strip. In the West Bank (the solid line), the unadjusted wage gap reached its minimum ( 2 percent) in 2003 during the Second Intifada and the maximum value occurred in 2009 (12 percent), always favoring non-refugees. In Gaza, the wage gap represents the annual average difference between Palestinian refugees' and Palestinian non-refugees' LN daily wage. The former always enjoy a positive wage premium over the latter. The wage gap in Gaza increased at a continuous rate during the period of interest and reached 22 percent in 2007, then decreased to 17 percent in 2012. In the following section, the differences between worker characteristics and occupations in the two groups in Gaza and the West Bank will be discussed.

\footnotetext{
${ }^{8}$ The data show that the proportion of the population of refugees in Palestine in 2014 is estimated at 41.2 percent of the total Palestinian population living in Palestine and indicate that 25.2 percent of the population in the West Bank consists of refugees, while the percentage of refugees in the Gaza Strip is about 66.8 percent (PCBS 2015).
} 
Table 1: Descriptive Statistics

\begin{tabular}{lrr}
\hline \hline \multicolumn{3}{c}{ Panel A: Workers' characteristics } \\
\hline & Mean & \multicolumn{1}{c}{ SD } \\
Daily wage (NIS) & 77.795 & 44.453 \\
Log wage & 4.157 & 0.739 \\
Years of school & 11.236 & 4.001 \\
University degree (0/1) & 0.360 & 0.480 \\
Experience & 17.688 & 11.215 \\
Male & 0.839 & \\
Employment in Israel (0/1) & 0.170 & \\
Private sector employment (0/1) & 0.564 & \\
Refugee status (0/1) & 0.479 & \\
Registered refugee (0/1) & 0.435 & \\
Married (0/1) & 0.438 & \\
\hline
\end{tabular}

Panel B: Regional and geographical characteristics

\begin{tabular}{lcc}
\hline & Mean & SD \\
West Bank & 0.689 & \\
Locality affected by the wall (1/0) & 0.102 & 0.303 \\
Percentage of the locality under area C & 0.049 & 0.128 \\
Locality type & & \\
Urban & 0.503 & \\
Rural & 0.305 \\
Camp Panel C: Sectoral and occupational distribution & \\
\hline \multicolumn{1}{c}{ Sectors } & $\mathbf{\%}$ \\
Agriculture & 0.053 \\
Manufacturing & 0.127 \\
Construction & 0.167 \\
Commerce & 0.099 \\
Transport & 0.032 \\
Service & 0.522 \\
Occupations & $\mathbf{\%}$ \\
Manager & 0.026 \\
Technical & 0.339 \\
Service & 0.145 \\
Skilled agriculture & 0.007 \\
Craft worker & 0.160 \\
Machine operation & 0.074 \\
Obmentary & 0.249 & \\
\hline \hline Observations & $\mathbf{2 2 4 , 7 9 4}$ & \\
\hline
\end{tabular}

Note: The sample is restricted to those individuals who are classified as being within the labor force during the period 1999-2012. Wages are measured in New Israeli shekels. Education is measured by years of schooling; percentage of the locality under area $\mathrm{C}$ is measured by the percentage point; and there is a dummy variable for other indicators, taking the value 1 if the variable exists and 0 otherwise. 
Figure 1: The Annual Wage Gap between Palestinian Refugees and Palestinian Nonrefugees, 1999-2012

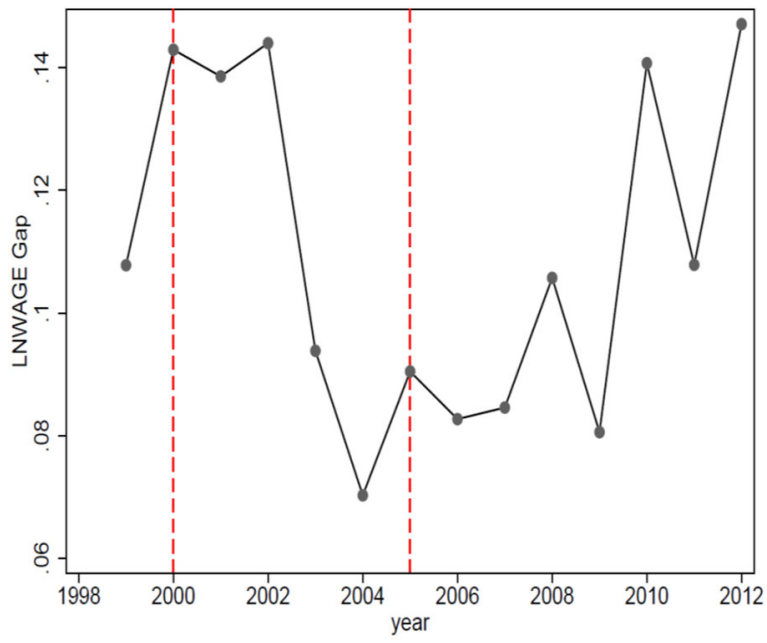

Source: Own calculations based on PCBS data.

Note: The wage gap represents the annual average difference between Palestinian non-refugees' and Palestinian refugees' natural logarithm in daily wages (LNWAGE) in the West Bank and the Gaza Strip between 1999Q1 and 2012Q4. The two dashed lines represent the beginning and end of the Second Palestinian Intifada (starting in 2000Q4 and ending 2005Q2).

Figure 2: The Distribution of the Natural Logarithm Daily Wages (LNWAGE) for Refugee and Non-refugee Workers in the West Bank and Gaza, 1999-2012
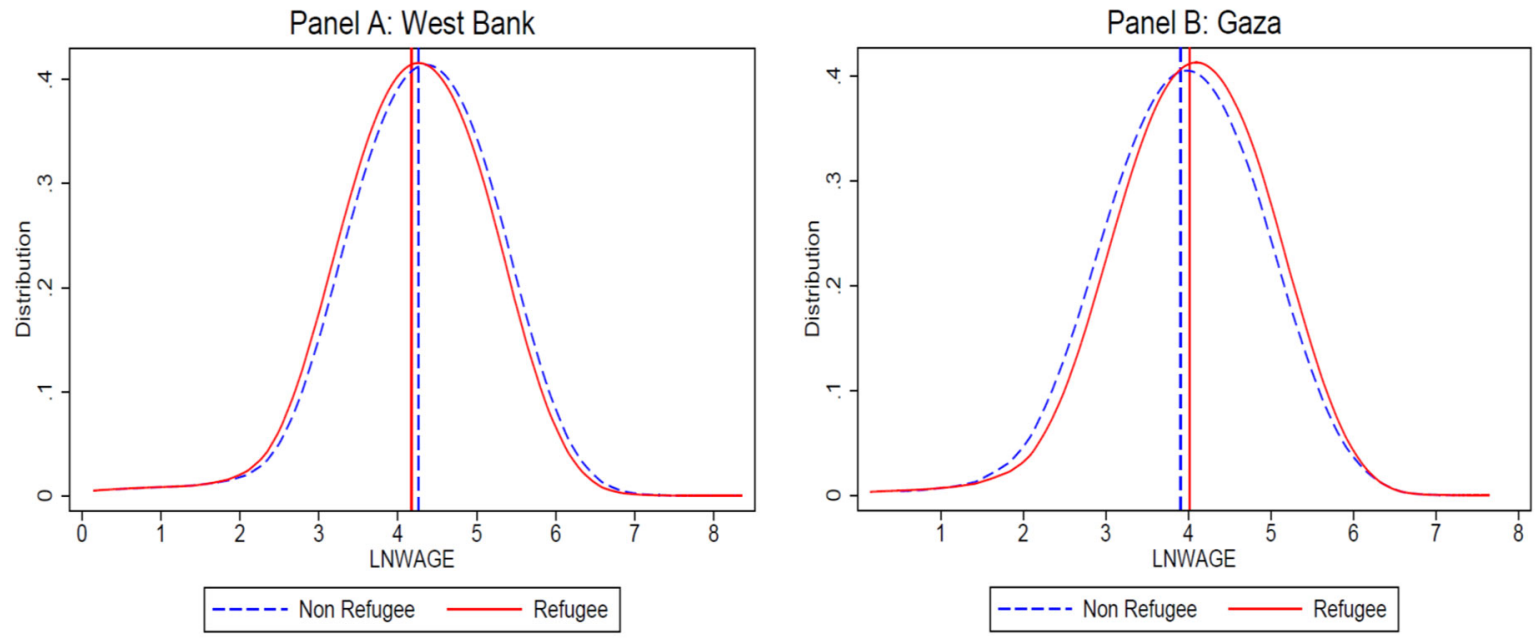

Source: Own calculations based on PCBS data.

Note: The vertical line represents the mean of the unadjusted LNWAGE for each group. The distribution is obtained by kernel density estimates, bandwidth $=0.7$. 
Figure 3: LNWAGE Gap over the Period (1999-2012) in the West Bank and Gaza

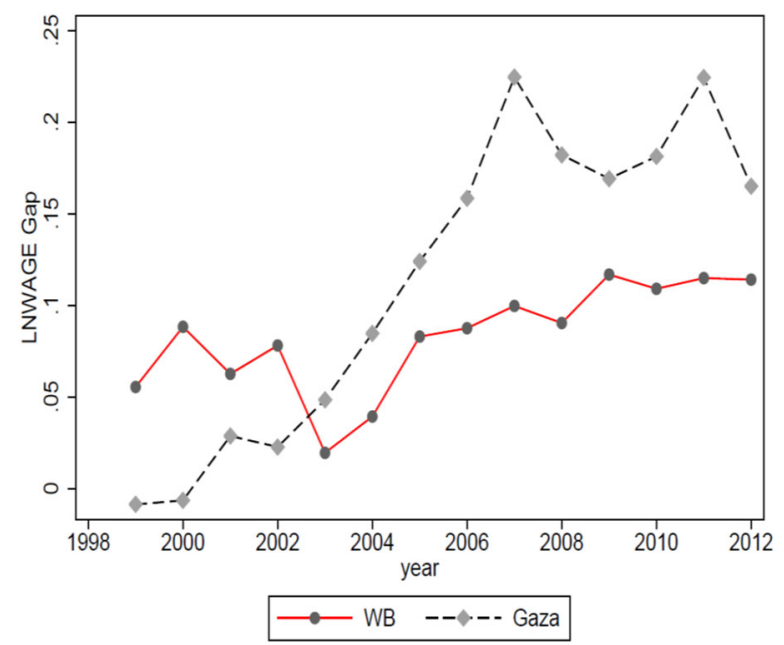

Source: Own calculations based on PCBS data.

Note: The solid line represents the wage gap between non-refugees and refugees in the West Bank, while the dashed line represents the differences between Palestinian refugees and Palestinian non-refugees in Gaza.

\section{WORKERS' CHARACTERISTICS AND OCCUPATIONAL DIFFERENCES}

Table 2 summarizes the means of the potential wage determinants for the period 1999-2012 for Palestinian refugees and Palestinian non-refugees in the West Bank and Gaza, respectively. Panel A shows the labor force attributes, while panel B presents the sectoral and occupational distribution for each group. The LN of real daily wage (LNWAGE) by refugee status is pooled for the years in the period of interest.

In the West Bank, the observed LNWAGE is higher for non-refugees, and the pooled wage gap is approximately 9 percent. In this table, two measures are used to control for the educational background of labor market participants_-years of schooling and tertiary degree — and Palestinians in the two groups have similar levels of education. The participation of males is overrepresented, with similar distributions (80 percent in the West Bank for the two groups). The two groups have the same experience and marital status, and a similar ratio of workers in the private sector. The main factor that might explain the wage difference favoring non-refugees 
is that the percentage of non-refugees working in Israel is higher than that observed among refugee workers (approximately one-third), since employment in Israel provides a wage premium over the local labor market. Refugees tend to be found more in the refugee camps, while non-refugees have similar distributions between urban and rural areas.

Panel B shows the occupational differences between the two groups in the West Bank and Gaza. The motivation for adding this table is that the wage differential literature has emphasized that the earnings gap is generated not only by individual differences but also by systematic variation in the occupational structure, which serves to exacerbate the effects of discrimination (Grodsky and Pager 2001; O’Neill 2003; Swed 2014). The differences in occupational choices are represented across six different sectors and seven occupational groups. The descriptive analysis shows similar distributions of the sector choice among Palestinian non-refugees and Palestinian refugees in the West Bank with the exception of two sectors: construction and services. The percentage of non-refugees in construction is higher than the refugees' share in the same sector by 5 percent. This is consistent with the results obtained in panel A, since construction represents the main sector for Palestinian employment in Israel, where non-refugees have a larger percentage of employment than refugees. One of the explanations for this distribution is likely to be related to the restricted labor mobility imposed on refugee camps during and after the Second Intifada. Notably, during the period of interest, the largest share of both population groups is found in the service sector, with a greater proportion of refugees. Columns 3 and 4 show that the unconditional mean wages are higher for Palestinian refugees than for nonrefugees in Gaza. This unadjusted wage gap is approximately 11 percent. Palestinian refugees in Gaza are better educated than non-refugees and have more experience. Similar to the West Bank, the share of non-refugee workers in Israel is larger than the share of refugees. The average occupational status (such as sector of occupation) of refugees in Gaza is similar to that of non-refugees, the only exception being found in technical occupations, in which the share of refugee workers is greater than that of non-refugees. 
Table 2: Descriptive Statistics-Differences between Non-refugees and Refugees in the West Bank and Gaza

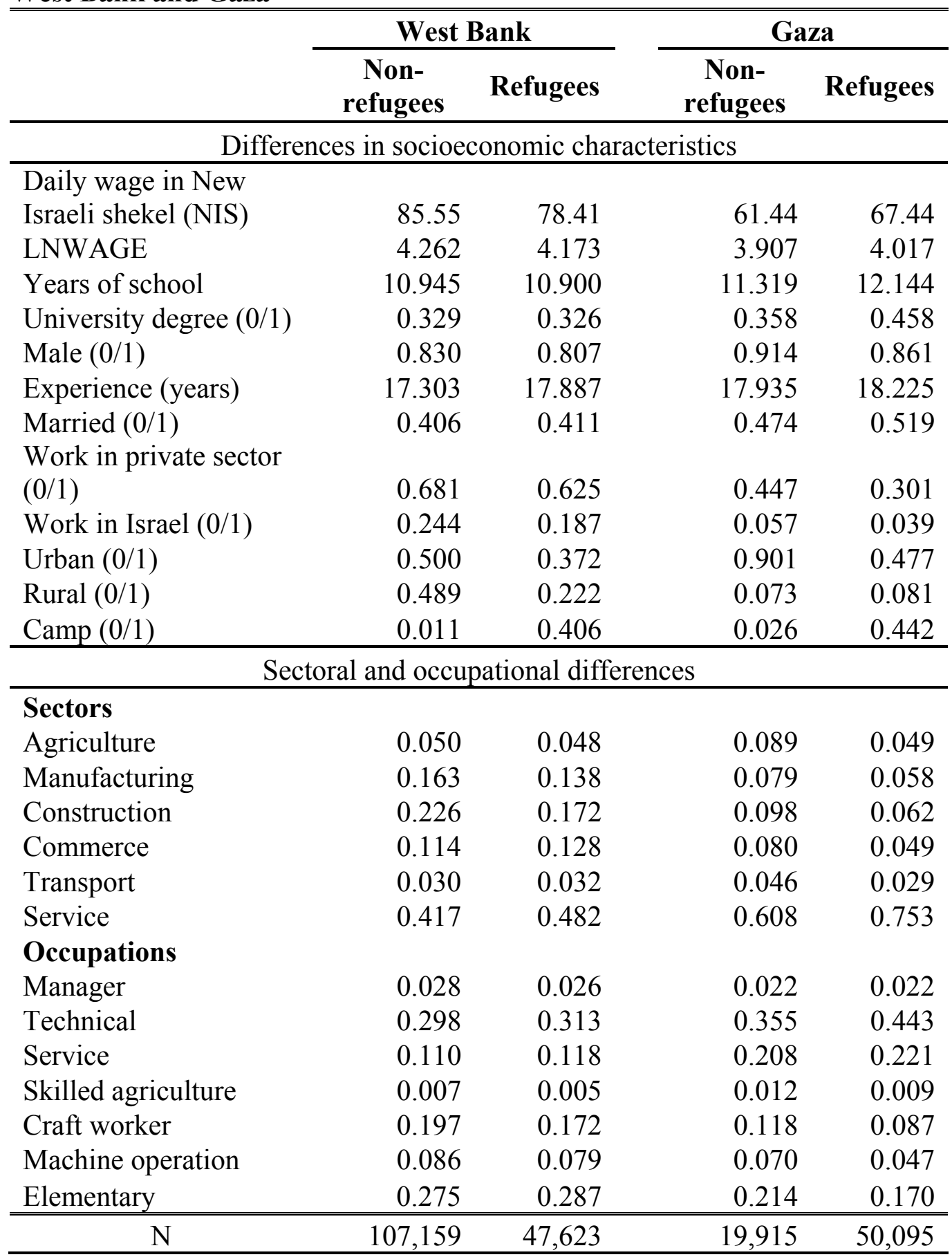

Source: Data collected by the PLFS (1999-2012) conducted by the PCBS. Wages are measured by the New Israeli Shekel currency. Education are measured by years of schooling while there is a dummy variable for other indicators, take value 1 if the variable exists and 0 otherwise. 


\section{EMPIRICAL MODEL}

Following the literature, wage regression analysis was conducted to capture the wage differences between non-refugees and refugees in the Palestinian territories with a dummy variable for the refugee group. In the following model, workers' wages are a function of their demographic, human capital, and socioeconomic characteristics and are specified as follows:

$$
L n W_{i t j}=\alpha+\delta R_{i t j}+\beta X_{i t j}+d_{j}+q_{t}+e_{i t j}
$$

where $L n W_{i t j}$ is the LN of the daily wage of worker $i$ in quarter $t$ in district $j$. A dummy variable, $R_{i t}$, takes the value of one if respondent $i$ in quarter $t$ in district $j$ is defined as a registered refugee and zero otherwise, and it captures the wage differential for refugees; $X_{i t j}$ captures the demographic, socioeconomic, and job classifications of worker $i$; $d_{j}$ stands for district fixed-effect dummies to control for cross-district differences, which vary little over time; $q_{t}$ represents the time (quarter) fixed effect. Finally, the term $e_{i t j}$ stands for the error term. The regressor vector $\mathrm{X}_{i \mathrm{ij}}$ includes gender, experience, and experience squared to account for lifecycle wage earnings, years of schooling, personal status (a dummy takes the value one if the worker is married and zero otherwise), and a set of industry sector dummies to account for any cross-industry wage differences. Seven occupational dummies are included to account for distinct profession-skill differences, and a variable takes the value one if the worker works in Israel and zero otherwise. Further, the estimation includes a set of locality type dummies to account for the wage differences between urban areas, rural areas, and refugee camps. In addition, the estimation includes a dummy variable to show whether the locality has been affected by the West Bank separation wall ${ }^{9}$ and the proportion of the locality under area C. ${ }^{10}$

\footnotetext{
${ }^{9}$ The Israeli West Bank barrier or wall is a separation barrier built by the Israeli government in the West Bank along the 1949 Armistice Line, known as the "Green Line" (B’Tselem 2012). The barrier divides Palestinian communities, encircles some, and isolates others from their surroundings while separating East Jerusalem from the rest of the West Bank (UNESCO 2014).

${ }^{10}$ Area C: Areas in the West Bank are still under full Israeli military and civil control based on the Oslo Accords of 1993, while the Palestinian Authority (PA) has civil and security control in area A. The PA has civil autonomy but no security control in area B (Vishwanath et al. 2014). Communities in area $\mathrm{C}$ are living in difficult life circumstances due to the lack of major services. Workers from area $\mathrm{C}$ also experience a wage penalty compared with other workers from localities in areas A and B (Fallah and Daoud 2015).
} 
Time (quarter) dummies are added to capture any time variation shocks in the region. All the standard errors are clustered at the locality level (worker's locality of residence).

The ordinary least squares (OLS) procedures as specified above do not control for workers' unobserved characteristics, such as their innate ability, which might affect the wage differences across workers. To estimate the extent to which any wage differential between Palestinian nonrefugees and Palestinian refugees is attributed to unobserved worker characteristics, the OaxacaBlinder (Oaxaca 1973) decomposition technique is employed to separate the wage gap into an explained part based on the observed characteristics (workers' endowment effect) and an unexplained part (unobserved workers' characteristics). The wage decomposition equation is specified as follows:

$$
\operatorname{Ln} W_{R=0}-\operatorname{Ln} W_{R=1}=(\underbrace{\left.\bar{X}_{\mathrm{R}=0}-\overline{\mathrm{X}}_{\mathrm{R}=1}\right) \beta_{\mathrm{R}=0}}_{\text {endowment }}+\underbrace{\overline{\mathrm{X}}_{\mathrm{R}=0}\left(\beta_{\mathrm{R}=0}-\beta_{\mathrm{R}=1}\right)}_{\text {coefficients }}+\underbrace{\left(\overline{\mathrm{X}}_{\mathrm{R}=0}-\overline{\mathrm{X}}_{\mathrm{R}=1}\right)\left(\beta_{\mathrm{R}=0}-\beta_{\mathrm{R}=1}\right)}_{\text {interaction }}
$$

The left-hand term is the difference in mean of the $\mathrm{LN}$ wages between non-refugees and refugees in Palestinian territories during the period of interest. The right-hand side consists of three parts. The first term is the human capital component of the overall wage gap; it is the difference in the distribution of average characteristics between workers according to their refugee status estimated in equation (1) (the endowment effect). The second and third parts together represent the unexplained component of the overall wage gap. The second term refers to the wage differential that is attributed to differences in the estimated coefficients of both models (it measures the expected change in refugee workers' wages if they have non-refugee workers' attributes). The third part is an interaction term that accounts for the difference in endowment and coefficient effects.

The validity of the Oaxaca-Blinder decomposition method depends largely on whether the model captures all the dimensions in which the skills of the two groups differ (Borjas and Van Ours 2010). One can argue that the estimation model seldom observes all the components that make up a worker's human capital, for example ability and the quality of education. In fact, the majority of Palestinian refugees enroll in UNRWA schooling systems, which provide free 
primary education until the ninth grade (UNESCO 2011). The UNRWA schools adopt the same national curriculum as the host country, and, in spite of the adverse circumstances in which Palestinian refugee students live, they achieve higher-than-average learning outcomes compared with other governmental school students, as indicated by the World Bank (Abdul-Hamid et al. 2015). Another factor that might affect the wage gap is the selection bias, and economists have dealt with this using the standard two-step estimation method proposed by Heckman (1974), which attempts to control for the selection by modeling what determines it. ${ }^{11}$ In the current study, the main coefficient (refugee status) is an exogenous factor and is obtained only through paternal inheritance.

\section{RESULTS}

\subsection{OLS Results}

Table 3 summarizes the OLS results from the estimation in equation (1). Panels A and B show the effect of being a refugee on workers' earnings in the West Bank and Gaza, respectively. The results present the estimations for the pooled sample of all 14 years. All the estimations include district and quarter fixed effects. The results in table 3 are obtained using different specifications to explore the extent to which workers' characteristics explain any refugee workers' wage differentials. The findings in panel A suggest that the status of being a refugee has a negative impact on workers' earnings even after controlling for their observable demographic characteristics. Adding the working in Israel dummy (in column 3) reduces the impact of the refugee status coefficient from 9 percent to 5 percent. Consistent with several works in the literature about the labor market in Palestine (Fallah 2017; Fallah and Daoud 2015; Mansour 2010; Miaari 2009), the working in Israel coefficient explains many labor wage differentials in Palestinian territories. In the employed sample, this coefficient provides a wage premium of more than 50 percent for West Bank workers and 85 percent for workers in Gaza. Column 4 presents the results after adding the set of all controls mentioned in equation (1) and demonstrates that the refugee coefficient still significantly reduces West Bank workers' wages (by 3 percent).

\footnotetext{
${ }^{11}$ Heckman's (1979) two-step estimation procedure is used to estimate the probit selection equation and the wage equation with the inverse Mills ratio.
} 
The registered refugees' distribution in the employed sample is significantly different in the West Bank than in the Gaza Strip. While they represent 29 percent of the West Bank labor force participants, their participation in Gaza reaches 70 percent. In Gaza, the refugee coefficient shows a significant positive impact on workers' earnings during the period of interest. This coefficient reduces approximately to half after adding workers' demographic characteristics (from 10 percent to 5 percent). Column 4 in panel B suggests that refugees earn 3 percent more than non-refugees with the same demographics and occupational attributes.

With regard to the control variables between the two regions, the return to education is similar for West Bank and Gaza workers after controlling for all the demographic and occupational variables, and males enjoy higher wages in both regions. 
Table 3: Effect of Refugee Status on Workers' Earnings

\begin{tabular}{|c|c|c|c|c|}
\hline Dep. variable: LNWAGE & (1) & (2) & (3) & (4) \\
\hline \multicolumn{5}{|c|}{ Panel A: West Bank } \\
\hline Refugee status & $\begin{array}{c}-0.087 * * * \\
(0.017)\end{array}$ & $\begin{array}{c}-0.090 * * * \\
(0.015)\end{array}$ & $\begin{array}{c}-0.059 * * * \\
(0.009)\end{array}$ & $\begin{array}{c}-0.032 * * * \\
(0.006)\end{array}$ \\
\hline Male & & $\begin{array}{c}0.384 * * * \\
(0.013)\end{array}$ & $\begin{array}{c}0.293 * * * \\
(0.010)\end{array}$ & $\begin{array}{c}0.292 * * * \\
(0.009)\end{array}$ \\
\hline Years of education & & $\begin{array}{c}0.039 * * * \\
(0.003)\end{array}$ & $\begin{array}{c}0.052 * * * \\
(0.002)\end{array}$ & $\begin{array}{c}0.038 * * * \\
(0.002)\end{array}$ \\
\hline Working in Israel & & & $\begin{array}{c}0.564 * * * \\
(0.020)\end{array}$ & $\begin{array}{c}0.530 * * * \\
(0.016)\end{array}$ \\
\hline $\begin{array}{l}\text { Observations } \\
\text { R-squared }\end{array}$ & $\begin{array}{c}154,703 \\
0.516\end{array}$ & $\begin{array}{c}154,694 \\
0.610\end{array}$ & $\begin{array}{c}154,694 \\
0.696\end{array}$ & $\begin{array}{c}154,657 \\
0.724\end{array}$ \\
\hline \multicolumn{5}{|c|}{ Panel B: Gaza Strip } \\
\hline Refugee status & $\begin{array}{c}0.102 * * * \\
(0.016)\end{array}$ & $\begin{array}{c}0.048^{* * *} \\
(0.010)\end{array}$ & $\begin{array}{c}0.059 * * * \\
(0.010)\end{array}$ & $\begin{array}{c}0.028 * * * \\
(0.007)\end{array}$ \\
\hline Male & & $\begin{array}{c}0.145^{* * *} \\
(0.013)\end{array}$ & $\begin{array}{c}0.136^{* * *} \\
(0.014)\end{array}$ & $\begin{array}{c}0.213 * * * \\
(0.016)\end{array}$ \\
\hline Years of education & & $\begin{array}{c}0.073 * * * \\
(0.002)\end{array}$ & $\begin{array}{c}0.078 * * * \\
(0.002)\end{array}$ & $\begin{array}{c}0.038 * * * \\
(0.001)\end{array}$ \\
\hline Working in Israel & & & $\begin{array}{c}0.846^{* * *} \\
(0.028)\end{array}$ & $\begin{array}{c}1.026 * * * \\
(0.025)\end{array}$ \\
\hline Observations & 70,010 & 70,010 & 70,010 & 70,010 \\
\hline R-squared & 0.342 & 0.547 & 0.594 & 0.691 \\
\hline District fixed effect & YES & YES & YES & YES \\
\hline Quarter fixed effect & YES & YES & YES & YES \\
\hline Demographic controls & NO & YES & YES & YES \\
\hline Locality control & NO & NO & NO & YES \\
\hline Occupation dummies & NO & NO & NO & YES \\
\hline Industry dummies & NO & NO & NO & YES \\
\hline Sector (private/public) & NO & $\mathrm{NO}$ & $\mathrm{NO}$ & YES \\
\hline
\end{tabular}

Note: The robust standard errors are in parentheses and clustered at the locality level. The data were collected from the PCBS Labor Force Survey (1999-2012). All the regressions' specifications are based on wage equations with the regressors gender, experience, experience squared, years of schooling, marital status, urban area/refugee camp residence, percentage of the locality under area $\mathrm{C}$, whether the locality was affected by the separation wall, a dummy for working in Israel, a dummy for working in the private sector, quarter and district fixed effects, and a set of occupational and industry dummies. Significance levels: ${ }^{* * *} \mathrm{p}<0.01,{ }^{* *} \mathrm{p}<0.05$, and ${ }^{*} \mathrm{p}<0.1$.

\subsection{Wage Gap Decomposition}

The previous section demonstrates that Palestinian refugees in the West Bank/Gaza earn lower/higher wages than their relative non-refugees, even after controlling for a large set of observable individual, socioeconomic, and geographical characteristics. Still, unobserved workers' effects might be influential. This also addresses the issue of whether the wage gap 
between the Palestinian non-refugees and refugees is justified by the wage components (along similar characteristics to the relative attributes) and whether there is discrimination against the Palestinian refugees. The following section contains two types of analysis: the first sheds light on the overall wage gap between the two groups in the Palestinian territory during the period 1999-2012 (pooled sample), while the second presents the analysis of the wage gap on an annual basis for the West Bank and Gaza workers separately.

The first column in table 4 presents the decomposition result for the West Bank workers' wage gap, while the results for the Gaza workers' wage gap decomposition are presented in the second column. The decomposition output contains two parts. The first panel reports the mean predictions by groups and their difference. In the employed sample, the mean of the daily LN wages for the West Bank workers is 4.262 for Palestinian non-refugees and 4.174 for Palestinian refugees, yielding a wage gap of 0.09 between the two groups. This wage gap is divided into two parts. The first part reflects the mean increase in refugees' wages if they have the same characteristics as non-refugees. This increase (0.0561) suggests that around 63 percent of the wage differential during the period 1999-2012 in the West Bank can be attributed to differences in workers' observed characteristics. The second part demonstrates the unexplained part of the wage differential between the two groups, which explains around 37 percent of the total wage gap. This part represents the second and third terms in 2, which quantifies the change in refugees' wages when applying the non-refugees' coefficients to refugees' characteristics and the interaction term that measures the simultaneous effect of differences in endowments and coefficients.

The second column in table 4 describes the wage differentials between the two groups in Gaza. The decomposition shows that Palestinian refugees face a positive wage premium of, on average, 11 percent. More than 78 percent of this wage gap is due to differences in workers' observed characteristics ( 8 percent), while the remainder (approximately 3 percent) can be interpreted as a positive wage premium due to difference in prices paid for the refugee workers' characteristics. 
Variable

Non-refugee

Refugee

LNWAGE differences
LNWAGE
$4.262 * * *$
$(0.00223)$
$4.174 * * *$
$(0.00336)$
$0.0885 * * *$

$(0.00404)$
LNWAGE

$3.907 * * *$

$(0.00520)$

$4.017 * * *$

$(0.00320)$

$-0.109 * * *$

$(0.00611)$

\section{Decomposition of the LNWAGE difference}

Explained by differences in workers' characteristics

Endowments

$0.0561 * * *$

$-0.0816^{* * *}$

Unexplained part: Coefficients

$0.0325 * * *$

$(0.00257)$

$-0.0276 * * *$

$(0.00379)$

Observations

154,690

70,010

Source: The data were collected from the PCBS Labor Force Survey (1999-2012). All the regressions' specifications are based on wage equations with the regressors gender, experience, experience squared, years of schooling, marital status, urban area/refugee camp residence, percentage of the locality under area C, whether the locality was affected by the separation wall, a dummy for working in Israel, a dummy for working in the private sector, quarter and district fixed effects, and a set of occupational and industry dummies.

Significance level: $* * * \mathrm{p}<0.01, * * \mathrm{p}<0.05$, and $* \mathrm{p}<0.1$.

The analyses in table 4 present the mean wage gaps between the two groups but do not provide information about how the wage gap varies by observed characteristics. Table 5 shows the decomposition results for selected variables. These variables are gender, schooling, experience, experience squared (to indicate seniority), working in Israel, and working in the private sector. Male workers have a wage premium over female workers, and the gender coefficient is in favor of non-refugee workers. With regard to education, the negative value for the unexplained part of the schooling coefficient indicates that educated refugees in the West Bank are paid more than non-refugees. One of the potential explanations for this result could be the fact that the UNRWA provides refugees with many work opportunities, particularly in the education and 
health service sectors, in which the salaries are determined administratively by the level of education and tenure rather than productivity (Tansel and Daoud 2011). ${ }^{12}$

Experience represents an important source of wage inequality. The negative value of the explained part of the experience coefficient means that the gap would increase if the two groups had equal experience. However, this discrimination is softened by the effect of the quadratic association between experience and wages, and the accumulated experience reduces the wage gap. ${ }^{13}$ As expected, working in Israel makes a significant contribution (more than 50 percent) to explaining the wage gap in favor of non-refugee laborers. Finally, wage discrimination against refugees tends to be more prevalent in the private sector, since much of its labor force tends to be classified as unskilled workers (Daoud and Shanti 2016; Miaari 2009).

The analysis in table 5A suggests that working in Israel explains much of the wage differential among different groups. For example, Swed (2014) attributed the decrease in the gender gap in the Palestinian territories during the Second Intifada to males' reduced ability to access the Israeli market due to the closure policy. Notably, some refugee camps in the West Bank experienced harsher movement restrictions due to greater involvement in violent conflict with the Israeli military during the Second Intifada than those in other localities. ${ }^{14} \mathrm{~A}$ reduced number of workers inside Israel can also explain part of the decreasing unadjusted wage gap between non-refugees and refugees during the Second Intifada, as figure 1 suggests. Palestinian employment in Israel started after the 1967 war. Part of the Israeli leadership encouraged the integration between the Palestinian and Israeli economies to improve the Palestinian peoples' quality of life. They argued that higher income and a low unemployment level would reduce Palestinian resistance to the occupation. On the other hand, this provided Palestinian access to

\footnotetext{
${ }^{12}$ Tansel and Daoud (2011) indicated that the highest return to education in Palestine during 2004 and 2008 was observed for workers employed in nongovernmental organizations (NGOs) and the UNRWA.

${ }^{13}$ In figures A5.a and A5.b, I use the STATA command "specify detail" (exp:exp*) to subsume experience and experience squared. Figure A5.a shows the effect of experience and its quadratic value together and suggests that the gap would increase if non-refugee and refugee workers had equal experience. In general, the coefficient for experience is expected to be positive (linear) and that for experience squared to be negative (nonlinear). Wages increase with age as people become more experienced, but with greater age, wages start to increase at a decreasing rate; at a certain point they do not grow (reaches the optimal wage level) and then start to fall (after retirement). ${ }^{14}$ During the Second Intifada, Israel took the initiative to bring the fighting to the refugee camps in Nablus and Jenin (Eiland 2010). For example, according to Human Rights Watch (2002), during Operation Defensive Shield in 2002, more than 50 Palestinians were killed in Jenin refugee camps, since this camp served as a launch site for numerous attacks against Israeli targets.
} 
Israeli territories, which would raise some concerns regarding Israel's security (Gazit 1995; Miaari, Zussman, and Zussman 2014). The Israeli government implemented two policies that severely affected the Palestinian labor market: substituting Palestinian labor with foreigners and imposing movement restrictions. These two factors are correlated and interdependent.

Increasing the movement restriction on Palestinian laborers would reduce their ability to access the Israeli market, increase absent days, and motivate Israeli employers to substitute them with foreigner workers (Miaari and Sauer 2011). Many factors play a significant role in creating barriers in front of Palestinian movements, such as closures, checkpoints, and curfews (Calì and Miaari 2013), and many localities in the West Bank are categorized as area $C$ and were affected by the separation wall after 2005 (Vishwanath et al. 2014). Figures A6.a and A6.b in the appendix show that, following the outbreak of the Second Intifada in September 2000, the number of Palestinians from both the West Bank and the Gaza Strip who were employed in Israel dropped sharply. This shock to the labor supply also had a heterogeneous impact on Palestinians' wages based on their educational attainment (skilled versus unskilled labor) (Mansour 2010) and employment sector and location (e.g., public versus private and rural versus urban wages) (Miaari 2009). Benmelech, Berrebi, and Klor (2010) indicated that Palestinian districts that were involved in conflict with Israel experienced more adverse economic consequences (an increase in unemployment, a decrease in wages, and a reduction in the number of Palestinians working in Israel) than other districts during the Second Intifada period.

The wage gap decomposition in Gaza was in favor of refugee workers. To avoid confusion of the coefficient sign, I change the reference group to non-refugees; therefore, unlike in the West Bank, the positive wage gap in table 5B represents the wage differential between refugees and non-refugees. The education and private sector coefficients explain most of this gap. Working in Israel gives a wage premium in Gaza to refugee workers; the wage gap will increase in favor of refugee workers if the two groups have access to the Israeli labor market. Neither experience nor accumulated experience plays a significant role in determining the wage gap between the two groups in Gaza. 
Tables 5A and 5B depict the wage gap decomposition for selected variables between the two groups in the two regions for the pooled sample of all 14 years.

Table 5A: Wage Decomposition for Selected Variables in the West Bank

\begin{tabular}{|c|c|c|c|}
\hline & $\begin{array}{c}(1) \\
\text { Differential }\end{array}$ & $\begin{array}{c}(2) \\
\text { Explained }\end{array}$ & $\begin{array}{c}\text { (3) } \\
\text { Unexplained }\end{array}$ \\
\hline Non-refugee LNWAGE & $\begin{array}{l}4.262 * * * \\
(0.00223)\end{array}$ & & \\
\hline Refugee LNWAGE & $\begin{array}{l}4.174 * * * \\
(0.00336)\end{array}$ & & \\
\hline LNWAGE differences & $\begin{array}{c}0.0885^{* * * *} \\
(0.00404)\end{array}$ & & \\
\hline Male & & $\begin{array}{c}0.00652 * * * \\
(0.000629)\end{array}$ & $\begin{array}{c}0.0528 * * * \\
(0.00556)\end{array}$ \\
\hline Years of education & & $\begin{array}{l}0.00171 * * \\
(0.000813)\end{array}$ & $\begin{array}{l}-0.0213 * * \\
(0.00996)\end{array}$ \\
\hline Experience & & $\begin{array}{c}-0.0142 * * * \\
(0.00153)\end{array}$ & $\begin{array}{l}0.0258 * \\
(0.0131)\end{array}$ \\
\hline Experience $^{2}$ & & $\begin{array}{c}0.00542 * * * \\
(0.000901)\end{array}$ & $\begin{array}{l}-0.0152 * * \\
(0.00683)\end{array}$ \\
\hline Working in Israel & & $\begin{array}{c}0.0302 * * * \\
(0.00118)\end{array}$ & $\begin{array}{c}-0.00829 * * * \\
(0.00123)\end{array}$ \\
\hline Private sector & & $\begin{array}{c}-0.00372 * * * \\
(0.000295)\end{array}$ & $\begin{array}{c}0.0515 * * * \\
(0.00579)\end{array}$ \\
\hline Constant & & & $\begin{array}{l}-0.00304 \\
(0.0307)\end{array}$ \\
\hline Total & & $\begin{array}{c}0.0561 * * * \\
(0.00371)\end{array}$ & $\begin{array}{c}0.0325 * * * \\
(0.00257)\end{array}$ \\
\hline
\end{tabular}

Source: The data were collected from the PCBS Labor Force Survey (1999-2012). All the regressions' specifications are based on wage equations with the regressors gender, experience, experience squared, years of schooling, marital status, urban area/refugee camp residence, percentage of the locality under area $\mathrm{C}$, whether the locality was affected by the separation wall, a dummy for working in Israel, a dummy for working in the private sector, quarter and district fixed effects, and a set of occupational and industry dummies.

Significance level: $* * * \mathrm{p}<0.01, * * \mathrm{p}<0.05$, and $* \mathrm{p}<0.1$. 
Table 5B: Wage Decomposition for Selected Variables in Gaza

(3)

Differential Explained Unexplained

\begin{tabular}{|c|c|c|c|}
\hline Refugee LNWAGE & $\begin{array}{l}4.017 * * * \\
(0.00320)\end{array}$ & & \\
\hline \multirow[t]{2}{*}{ Non-refugee LNWAGE } & $3.907 * * *$ & & \\
\hline & $(0.00520)$ & & \\
\hline \multirow[t]{2}{*}{ LNWAGE differences } & $0.109 * * *$ & & \\
\hline & $(0.00611)$ & & \\
\hline \multicolumn{4}{|c|}{ Wage decomposition for selected variables } \\
\hline \multirow[t]{2}{*}{ Male } & & $-0.0114 * * *$ & $-0.0696 * * *$ \\
\hline & & $(0.000619)$ & $(0.0132)$ \\
\hline \multirow[t]{2}{*}{ Years of education } & & $0.0311 * * *$ & 0.0234 \\
\hline & & $(0.00141)$ & $(0.0158)$ \\
\hline \multirow{2}{*}{ Experience } & & $0.00931 * * *$ & -0.0290 \\
\hline & & $(0.00293)$ & $(0.0256)$ \\
\hline \multirow[t]{2}{*}{ Experience $^{2}$} & & -0.00196 & 0.0129 \\
\hline & & $(0.00193)$ & $(0.0137)$ \\
\hline \multirow[t]{2}{*}{ Work in Israel } & & $-0.0190 * * *$ & $-0.00309 * * *$ \\
\hline & & $(0.00191)$ & $(0.000979)$ \\
\hline \multirow[t]{2}{*}{ Private sector } & & $0.0523 * * *$ & $-0.0170 * *$ \\
\hline & & $(0.00201)$ & $(0.00800)$ \\
\hline \multirow[t]{2}{*}{ Constant } & & & 0.0278 \\
\hline & & & $(0.0509)$ \\
\hline \multirow[t]{2}{*}{ Total } & & $0.0816 * * *$ & $0.0276^{* * *}$ \\
\hline & & $(0.00542)$ & $(0.00379)$ \\
\hline Observations & 70,010 & & \\
\hline
\end{tabular}

Source: The data were collected from the PCBS Labor Force Survey (1999-2012). All the regressions' specifications are based on wage equations with the regressors gender, experience, experience squared, years of schooling, marital status, urban area/refugee camp residence, percentage of the locality under area $\mathrm{C}$, whether the locality was affected by the separation wall, a dummy for working in Israel, a dummy for working in the private sector, quarter and district fixed effects, and a set of occupational and industry dummies. Significance level: ${ }^{* * *} \mathrm{p}<0.01,{ }^{* *} \mathrm{p}<0.05$, and $* \mathrm{p}<0.1$.

Next, the wage differentials between the two groups in the West Bank and Gaza over time are analyzed. To avoid an estimation bias that would mask any wage differential between nonrefugees and refugees, the following analyses do not include observations for workers who 
report their place of work as Israel or Israeli settlements. ${ }^{15}$ Those workers represent 17 percent of the overall sample. ${ }^{16}$

The numbers in table 6, column 3 indicate the mean of the LNWAGE between the non-refugee and the refugee Palestinian workers in the West Bank (panel A) and the Gaza Strip (panel B). Column 4 represents the sum or aggregate of the endowment effect ("the explained difference"), while the treatment effect ("the unexplained difference") is presented in column 5. In the West Bank, the wage gap decreases over the last two years of the Second Uprising period (2003-4) and then increases rapidly over time. This gap reaches its peak in 2009 and then decreases during the following years. The analysis in panel A also shows that, during the Second Intifada (2001-5), most of the wage gap is attributed to the endowment effect due to the differences in observed characteristics among the two groups. Then, after 2007, a greater weight is given to the treatment effect. Notably, in 1999, before the Second Intifada, the large positive endowment impact on refugees' characteristics is offset by the negative treatment effect component.

Furthermore, the explained part in 2011 shows a negative result, which suggests that the gap would increase if the two groups had equal observed characteristics; this could indicate wage discrimination against refugees. In most cases, both the treatment effect and the endowment effect are positive and work in the same direction to provide a remarkable wage premium to non-refugee workers over refugees. More than 50 percent of this premium, especially after the Second Intifada, is due to the treatment effect.

Panel B presents the wage gap between non-refugees and refugees among Gazan workers. The wage gap increases rapidly over time to the advantage of the refugees' group. Within 14 years, the wage gap increased from 6 percent in 1999 to 17 percent in 2012. After the Second Intifada,

\footnotetext{
${ }^{15}$ A strand of the existing literature on Palestinian economics has eliminated employment in Israeli when trying to explain the wage differential in the Palestinian labor market; for example, see Fallah (2017), Fallah and Daoud (2015), and Miaari (2009).

${ }^{16}$ The percentage of employment in Israel varies significantly between the West Bank and Gaza. While those workers represent 22.75 percent of the West Bank sample (35,959 observations), in Gaza they only account for 4.39 percent $(3,074)$ of observations. According to the regression results in table 3 , working in Israel gives Palestinian laborers, on average, a 55 percent wage premium in the West Bank and a more than 80 percent wage premium in Gaza.
} 
the vast majority of the wage gap is attributable to the endowment effect, while the treatment effect had more significant influence in earlier years of the study.

The results show that, in the pre-Intifada period, the wage gap between non-refugee and refugee workers was at its lowest level, with an opposite direction in both the West Bank (in favor of non-refugees) and the Gaza Strip (in favor of refugees). However, in the post-Intifada period, a sharp increase is observed to the favor of refugees in the Gaza Strip. In contrast, the wage gap in the West Bank increased sharply only in 2009, then declined to the level close to that observed during the Second Intifada period. This wage gap consistently favors non-refugee workers. The results show a wage penalty for having refugee status in the West Bank, and a large part of this penalty can be attributed to the unexplained effect of wage decomposition components.

Figure 4 depicts the wage gap decomposition between 1999 and 2012 between the two groups in the two regions (panel A). In panel B, the wage gap represents the wage differential between refugee and non-refugee workers in Gaza. 
Table 6: Decomposing the Wage Differential over Time

\begin{tabular}{|c|c|c|c|c|c|c|}
\hline \multirow[b]{3}{*}{ Year } & \multirow[b]{3}{*}{ Observations } & (3) & (4) & (5) & (6) & (7) \\
\hline & & \multirow[b]{2}{*}{$\begin{array}{l}\text { LNWAGE } \\
\text { gap }\end{array}$} & \multirow[b]{2}{*}{ Explained } & \multirow[b]{2}{*}{ Unexplained } & \multicolumn{2}{|c|}{$\%$} \\
\hline & & & & & Explained & Unexplained \\
\hline \multicolumn{7}{|c|}{ Panel A: West Bank } \\
\hline 1999 & 7,224 & 0.028 & 0.041 & -0.014 & 149 & -49 \\
\hline 2000 & 9,485 & 0.066 & 0.047 & 0.019 & 72 & 28 \\
\hline 2001 & 7,721 & 0.049 & 0.033 & 0.015 & 68 & 32 \\
\hline 2002 & 5,646 & 0.062 & 0.036 & 0.026 & 58 & 42 \\
\hline 2003 & 6,931 & 0.015 & 0.009 & 0.006 & 57 & 43 \\
\hline 2004 & 6,985 & 0.034 & 0.025 & 0.009 & 73 & 27 \\
\hline 2005 & 8,538 & 0.064 & 0.039 & 0.025 & 61 & 39 \\
\hline 2006 & 8,987 & 0.069 & 0.031 & 0.038 & 45 & 55 \\
\hline 2007 & 9,054 & 0.071 & 0.039 & 0.032 & 55 & 45 \\
\hline 2008 & 6,847 & 0.058 & 0.014 & 0.044 & 24 & 76 \\
\hline 2009 & 10,085 & 0.102 & 0.045 & 0.057 & 44 & 56 \\
\hline 2010 & 10,675 & 0.047 & 0.001 & 0.046 & 2 & 98 \\
\hline 2011 & 11,249 & 0.048 & -0.002 & 0.050 & -5 & 105 \\
\hline 2012 & 10,191 & 0.049 & 0.023 & 0.026 & 46 & 54 \\
\hline \multicolumn{7}{|c|}{ Panel B: Gaza Strip } \\
\hline 1999 & 3,997 & -0.060 & -0.032 & -0.028 & 53 & 47 \\
\hline 2000 & 5,387 & -0.058 & -0.016 & -0.043 & 27 & 73 \\
\hline 2001 & 4,466 & -0.037 & 0.001 & -0.038 & -2 & 102 \\
\hline 2002 & 3,672 & -0.046 & 0.032 & -0.078 & -70 & 170 \\
\hline 2003 & 4,536 & -0.077 & -0.048 & -0.029 & 63 & 37 \\
\hline 2004 & 4,439 & -0.098 & -0.076 & -0.022 & 78 & 22 \\
\hline 2005 & 5,041 & -0.132 & -0.116 & -0.016 & 88 & 12 \\
\hline 2006 & 4,572 & -0.158 & -0.138 & -0.020 & 87 & 13 \\
\hline 2007 & 4,831 & -0.225 & -0.181 & -0.044 & 80 & 20 \\
\hline 2008 & 2,814 & -0.183 & -0.181 & -0.002 & 99 & 1 \\
\hline 2009 & 5,105 & -0.169 & -0.164 & -0.005 & 97 & 3 \\
\hline 2010 & 5,357 & -0.181 & -0.198 & 0.017 & 109 & -9 \\
\hline 2011 & 6,305 & -0.224 & -0.203 & -0.021 & 91 & 9 \\
\hline 2012 & 6,414 & -0.165 & -0.162 & -0.003 & 98 & 2 \\
\hline
\end{tabular}

Note: Specifications based on wage equations with the regressors gender, experience, experience squared, years of schooling, personal status, urban area/refugee camp residence, percentage of the locality under area $\mathrm{C}$, whether the locality was affected by the separation wall, the quarterly fixed effect, a dummy for working in the private sector, and a set of occupational and industry dummies. The analysis does not include laborers working in Israel.

LNWAGE represents the difference in the $L N$ wages between non-refugee and refugee workers. "Explained" refers to the human capital component of the wage gap (endowment effect), and "unexplained" refers to the treatment effect component of the wage gap. All the items in bold typeface are statistically significant at the conventional level of 5 percent or better. The wage gap in both regions represents the difference between the LNWAGE of nonrefugee and refugee workers. 
Figure 4: Wage Gap Decomposition over the Period 1999-2012

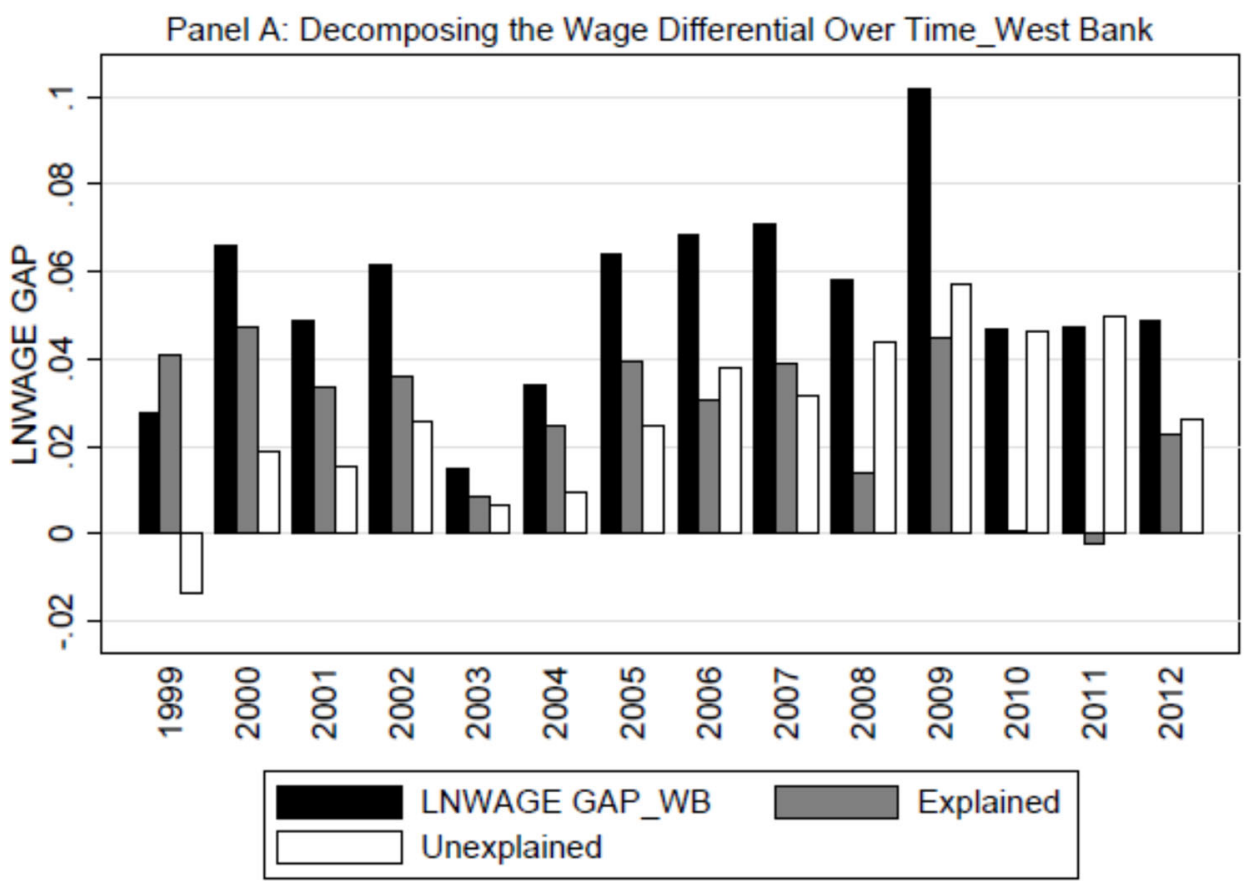

Note: The wage gap represents the differences between non-refugees' and refugees' salaries in the West Bank.

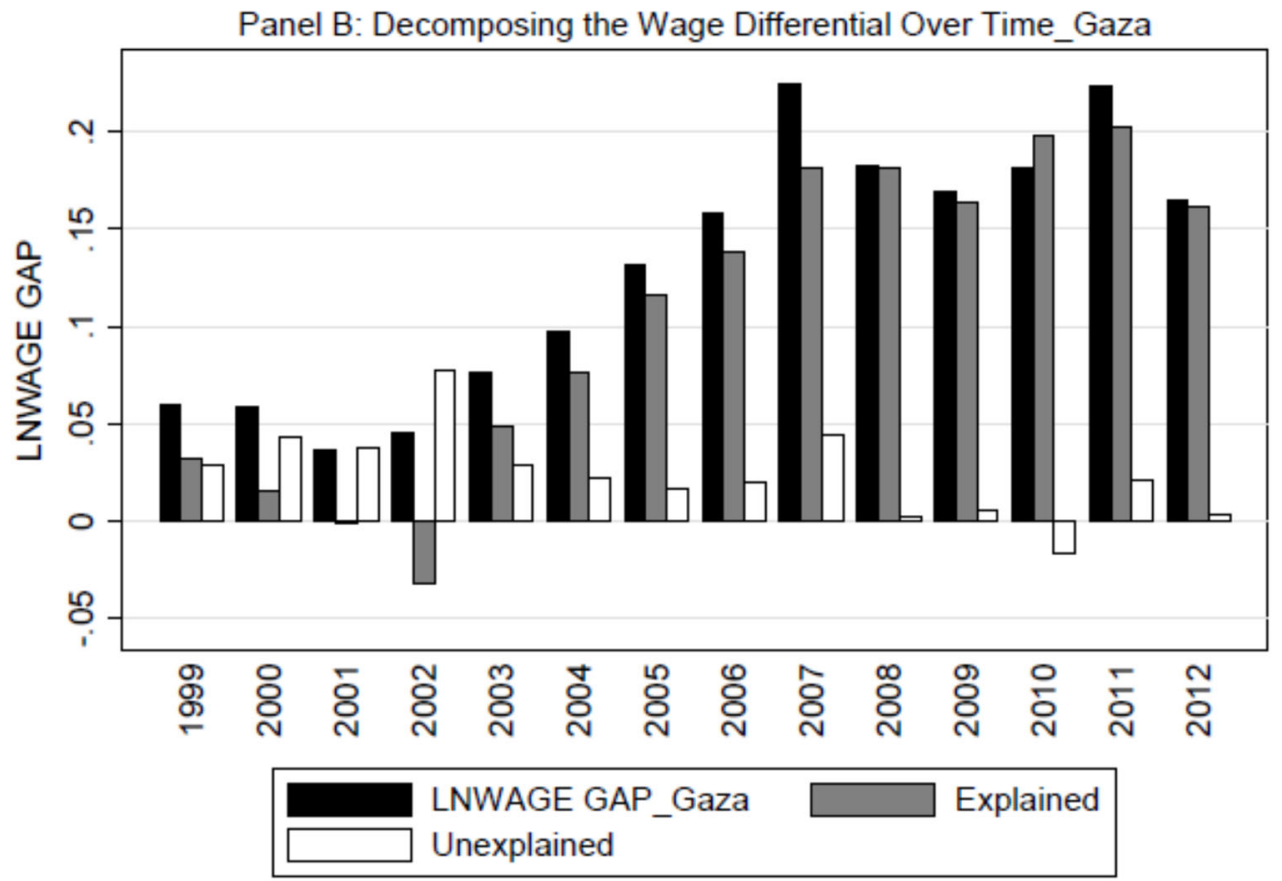

Note: The wage gap represents the differences between refugees' and non-refugees' salaries in Gaza. Source: Own calculations based on PCBS data. 


\subsection{Wage Gap for Skilled and Unskilled Workers}

Employment policies in the Palestinian territories, such as the minimum wage, antidiscrimination, equal employment opportunities, and other employee benefits, are regulated by the applied Palestinian labor law. However, the compliance rate with these regulations is higher in skilled labor jobs that require more than 12 years of education than in unskilled labor jobs (Fallah 2016). Less-skilled workers usually look for employment in Israel, since it provides better wages. Thus, wages for less-skilled workers are more adversely affected by closures than those for highly skilled labor (Mansour 2010). The unskilled workers in the Palestinian labor market are homogeneous, so we would expect the wage gap, if it exists, to be attributed more to the treatment effect than the endowment component (Miaari 2009). Table 7 presents the decomposition of the wage gap for skilled workers, which increased during the first two years of the Second Intifada. Then it decreased until the last three years of the study period, when the gap became close to the unskilled workers' wage gap. Before and during the Second Intifada, the endowment effect contributed the vast majority of the wage gap among the unskilled workers in the West Bank, while most of the wage differential after 2007 is attributed to the treatment effect. A possible explanation may lie in the availability of few working opportunities for low-skilled refugee workers in their host communities. The only exception can be found in 2006 and 2007, two years after the Second Intifada was over, when the wage gap among unskilled workers reached the maximum level, and both the endowment and the treatment effect make a significant contribution to explaining this gap. In Gaza, the wage gap for both skilled and unskilled labor increased over the period 1999-2012. Similar to the West Bank, the wage gap among unskilled laborers is greater than the skilled labor wage gap but favors refugees. Unlike the West Bank, the human capital component among skilled workers made up the majority of the overall wage gap until 2006-when Hamas controlled the Palestinian Legislative Council elections and commanded the Gaza Strip overall in 2007—and the treatment effect had a more significant impact in the following years. Most of the wage gap among unskilled workers over the years is explained by the endowment compensation and follows the pattern of the overall gross gap. 
Table 7: Wage Differential Decomposition by Skill Group

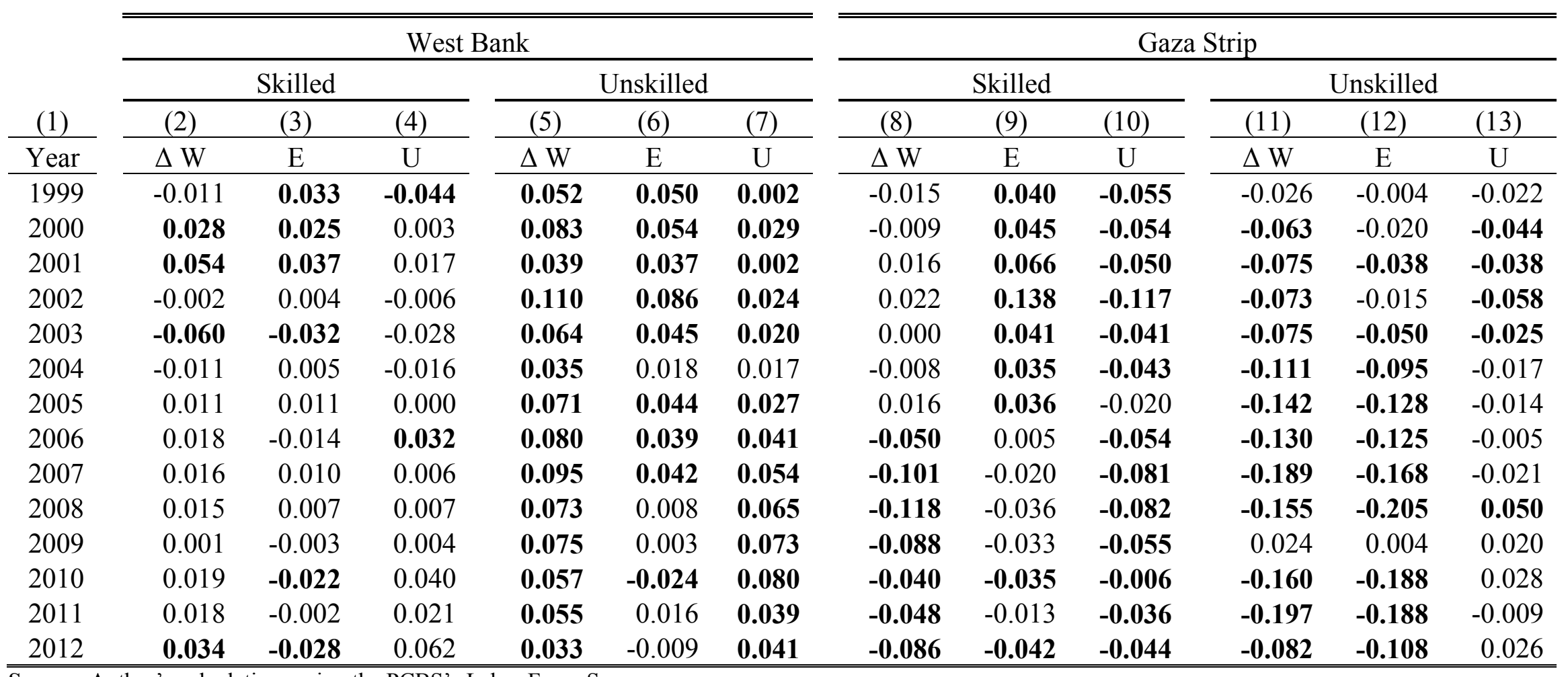

Source: Author's calculations using the PCBS's Labor Force Survey.

Notes: A skilled worker is defined as one with more than 12 years of schooling. The specifications are based on wage equations with the regressors gender, experience, experience squared, years of schooling, personal status, urban area/refugee camp residence, percentage of the locality under area $\mathrm{C}$, whether the locality was affected by the separation wall, the quarter fixed effect, a dummy for private sector employment, and a set of occupational and industry dummies. The analyses do not include laborers working in Israel. $\Delta \mathrm{W}$ represents the difference in the daily LN wages between non-refugee and refugee workers, E refers to the explained human capital component of the wage gap (endowment effect), and $\mathrm{U}$ refers to the unexplained (treatment effect) component of the wage gap. All the items in bold typeface are statistically significant at the conventional level of 10 percent or better. The wage gap in both regions represents the difference between the LNWAGE of non-refugee and refugee workers. 


\section{ROBUSTNESS CHECKS}

Table 8 provides additional results that are consistent with the main findings in this work. In panel A, all refugees are included in the sample, regardless of their registration status; the number of Palestinian refugees in the working sample increases by approximately 9,800 observations. ${ }^{17}$ The period is divided into three periods: before, during, and after the Second Palestinian Intifada (October 2000-May 2005), since it caused a significant shock to the Palestinian labor market (Di Maio and Nandi 2013; Mansour 2010; Miaari 2009). ${ }^{18}$ All the estimations include the set of all the controls mentioned in equation (1) in addition to the district and quarter fixed effects. The estimations do not include observations that recorded their working place as Israel. Similar to the results obtained in table 3, the findings show the same pattern of effects, except before the Second Intifada period, when the coefficient gives an insignificant negative/positive sign in the two regions. In the West Bank, and after the Second Intifada, Palestinian refugees earn about 4 percent less than non-refugees with the same demographic and socioeconomic characteristics. This adverse effect is approximately twice as large as the percentage obtained during the Second Intifada periods. In Gaza, the effect of the refugee coefficient increases to 4 percent during the Second Intifada and then decreases after this period but still has a significant positive impact; it gives refugees a wage premium of 2 percent more than non-refugees after the Second Intifada.

Panel B shows an interaction dummy for whether the respondent is a refugee and lives in a camp. Despite the fact that Palestinian refugees have the same citizenship and legal status as non-refugees in the West Bank and the Gaza Strip, social discrimination and other forms of mistreatment toward refugees residing in camps are increasingly prevalent (Al Husseini and Bocco 2009; PCBS 2010). ${ }^{19}$ In the West Bank, the effect of the interaction dummy is significantly larger than the refugee coefficient alone. During and after the Second Intifada, the

\footnotetext{
17 The UNRWA does not recognize the Palestinian refugees who did not seek refugee status in one of UNRWA's fields of operations, those who chose not to register with it (Al Husseini and Bocco 2009), and the Palestinians who lost their land and their property as a result of the 1967 war (MIFTAH 2003).

${ }^{18}$ In all the calculations, the Second Intifada started in 2000Q4 and ended in 2005Q2.

19 The perceived discrimination against refugees in the West Bank and the Gaza Strip is less than that in other countries, like Syria and Lebanon (Al Husseini and Bocco 2009).
} 
interaction coefficient increased from 5 percent to 10 percent, which is more substantial than the impact of refugee status on workers' earnings displayed in table 3, panel A.

In Gaza, the sign for the interaction coefficient during the three periods changes and becomes negative but insignificant. These results suggest that Palestinians living in camps have the worst living conditions of all Palestinian citizens. However, UNRWA services are provided for registered refugees regardless of their economic status (Al Husseini and Bocco 2009). The results in panel $\mathrm{C}$ show the effect of the refugee coefficient on the unemployment status of the respondents. All the estimations are obtained by probit estimation, and the outcome variable takes the value one if the respondent was unemployed during the quarter of the survey and zero otherwise. Before and during the Second Intifada, refugee status has no significant impact on unemployment. After the Second Intifada, the refugee coefficient increases the individual probability of being unemployed by 15 percent in the West Bank and 6 percent in Gaza. These results are interesting, since the unemployment rate in all Palestinian territories during the Second Intifada was the highest compared with the overall rates in the years after the Second Intifada due to mobility restrictions (Mansour 2010; Miaari, Zussman, and Zussman 2014).

Table 9 shows the different impacts of refugee status on earnings according to workers' gender and employment sector. In Palestine, a gender wage gap exists in favor of males (Swed 2014). The return to schooling favors women and plays a remarkable role in decreasing the gender wage differentials (Daoud 2005; Rizk 2016; Swed 2014; Tansel and Daoud 2011). Furthermore, the less-educated labor force is found to be in the private sector, since this sector is competing not only with the public sector but also with many nongovernmental organizations to recruit and retain employees with high levels of human capital formation (Daoud and Shanti 2016). During and after the Second Intifada, the Palestinian labor market experienced a rapid decrease in private sector wages; this was due to an increase in the Palestinian labor supply as a result of the sharp decline in the number of Palestinians working in Israel (Miaari 2009). In panel A, columns 2 and 4, the refugee status coefficient has a more adverse impact on males' earnings and on private sector wages in the West Bank than the coefficient obtained for the entire sample in table 3, while the impact on females' earnings and on public sector wages is close to zero. These results are consistent with the results displayed in table 7, since skilled labor is found 
more in the public sector, in which the gap in skilled laborers' wages is too small and most of this gap, if it exists, is explained by the endowment effect. In Gaza, the results are in line with the main results for the positive influence of the refugee coefficient on female/male workers' earnings in the public sector only, while this impact vanishes in private sector wages.

Panel B in table 9 provides evidence that gender differences exist by sector of employment. In both regions, the gender differences for refugees' status are in favor of females, and they are more significant in the public than in the private sector. ${ }^{20}$ According to figures A1.a and A1.b, the share of workers in the private sector in the West Bank is larger than that in the public sector for both groups. Meanwhile, in Gaza, public employment consists of a more substantial share of workers than the private sector, as shown in figures A2.a and A2.b. The only exception is during the pre-Second Intifada period (1999-2000), when non-refugee workers in Gaza tended to be observed more in the private sector, while refugee workers were more concentrated in the public sector, which includes employment in the UNRWA. Figures A3 and A4 in the appendix show the wage gap decomposition by gender over period in the two regions. In contrast to males' wages in the West Bank, female refugees enjoy positive wage gaps in most years, and a significant part of this wage premium reflects differences in individual human capital. In Gaza, the wage differential decomposition results for females and males show the same trend. However, even though most of the wage gap in Gaza is due to differences in workers' characteristics (the explained wage gap), differences in the prices paid for the employees' characteristics (the unexplained wage gap) are more prevalent in females' wage gap.

\footnotetext{
${ }^{20}$ Fallah (2017) indicated the important role of public employment in the West Bank in both tradable and nontradable sectors through the positive impact of public employment on the number of local entrepreneurs (employers and self-employed).
} 
Table 8: Robustness Checks-The Effect of Refugee Status on Wages and Unemployment

\begin{tabular}{|c|c|c|c|c|c|c|}
\hline & \multicolumn{2}{|c|}{$\begin{array}{c}\text { Before the } \\
\text { Second Intifada } \\
1999-2000 \\
\end{array}$} & \multicolumn{2}{|c|}{$\begin{array}{c}\text { During the } \\
\text { Second Intifada } \\
2001-4\end{array}$} & \multicolumn{2}{|c|}{$\begin{array}{c}\text { After the } \\
\text { Second Intifada } \\
2005-12\end{array}$} \\
\hline & $\begin{array}{c}(1) \\
\text { West } \\
\text { Bank } \\
\end{array}$ & $\begin{array}{c}(2) \\
\text { Gaza }\end{array}$ & $\begin{array}{c}(3) \\
\text { West } \\
\text { Bank } \\
\end{array}$ & $\begin{array}{c}\text { (4) } \\
\text { Gaza }\end{array}$ & $\begin{array}{c}(5) \\
\text { West } \\
\text { Bank } \\
\end{array}$ & $\begin{array}{c}(9) \\
\text { Gaza }\end{array}$ \\
\hline \multicolumn{7}{|c|}{ Panel A -Dependent variable: LNWAGE, OLS estimation } \\
\hline Refugee & $\begin{array}{l}-0.0130 \\
(0.0105)\end{array}$ & $\begin{array}{c}0.0245 \\
(0.0193)\end{array}$ & $\begin{array}{l}-0.0157 * \\
(0.00862)\end{array}$ & $\begin{array}{l}0.0392 * * * \\
(0.00838)\end{array}$ & $\begin{array}{c}- \\
0.0388 * * * \\
(0.00726)\end{array}$ & $\begin{array}{c}0.0186^{*} \\
(0.00955)\end{array}$ \\
\hline R-squared & 0.493 & 0.621 & 0.500 & 0.427 & 0.788 & 0.757 \\
\hline \multicolumn{7}{|c|}{ Panel B - Dependent variable: LNWAGE, OLS estimation } \\
\hline $\begin{array}{l}\text { Registered refugee } \\
* \text { lives in a camp }\end{array}$ & $\begin{array}{l}-0.060 \\
(0.043)\end{array}$ & $\begin{array}{l}-0.042 \\
(0.057)\end{array}$ & $\begin{array}{l}-0.053 * \\
(0.029)\end{array}$ & $\begin{array}{l}-0.042 \\
(0.035)\end{array}$ & $\begin{array}{c}-0.103 * * * \\
(0.028)\end{array}$ & $\begin{array}{l}-0.015 \\
(0.026)\end{array}$ \\
\hline R-squared & 0.495 & 0.625 & 0.500 & 0.436 & 0.790 & 0.774 \\
\hline \multicolumn{7}{|c|}{ Panel C - Dependent variable: Unemployment, probit estimation } \\
\hline Registered refugee & $\begin{array}{c}0.008 \\
(0.053) \\
\end{array}$ & $\begin{array}{l}-0.042 \\
(0.109) \\
\end{array}$ & $\begin{array}{c}0.021 \\
(0.042) \\
\end{array}$ & $\begin{array}{c}0.015 \\
(0.040) \\
\end{array}$ & $\begin{array}{c}0.151 * * * \\
(0.025) \\
\end{array}$ & $\begin{array}{l}0.059 * \\
(0.032) \\
\end{array}$ \\
\hline Observations & 19,184 & 8,747 & 36,482 & 18,722 & 92,428 & 39,292 \\
\hline
\end{tabular}

Notes: The robust standard errors are in parentheses and clustered at the locality level. The data were collected from the PCBS Labor Force Survey (1999-2012). All the regressions' specifications are based on wage equations with the regressors gender, experience, experience squared, years of schooling, marital status, urban area/refugee camp residence, percentage of the locality under area $\mathrm{C}$, whether the locality was affected by the separation wall, an employment sector dummy, quarter and district fixed effects, and a set of occupational and industry dummies. In all the estimations, the Second Intifada started in 2000Q4 and ended in 2005Q2. The analyses do not include observations of workers who report their place of work to be Israel or Israeli settlements. Significance level: *** $\mathrm{p}<0.01, * * \mathrm{p}<0.05$, and $* \mathrm{p}<0.1$. 
Table 9: Effect of Registered Refugee Status on Wages According to Employment Sector and Workers' Gender

\begin{tabular}{|c|c|c|c|c|c|c|c|c|}
\hline & \multicolumn{4}{|c|}{ West Bank } & \multicolumn{4}{|c|}{ Gaza } \\
\hline & $(1)$ & $(2)$ & $(3)$ & $(4)$ & $(5)$ & $(6)$ & $(7)$ & $(8)$ \\
\hline \multicolumn{9}{|c|}{ Panel A - Effect of the refugee coefficient according to gender and employment sector } \\
\hline & Female & Male & $\begin{array}{l}\text { Public } \\
\text { sector }\end{array}$ & $\begin{array}{c}\text { Private } \\
\text { sector }\end{array}$ & Female & Male & $\begin{array}{l}\text { Public } \\
\text { sector }\end{array}$ & $\begin{array}{c}\text { Private } \\
\text { sector }\end{array}$ \\
\hline $\begin{array}{l}\text { Registered } \\
\text { refugee }\end{array}$ & $\begin{array}{c}0.006 \\
(0.011)\end{array}$ & $\begin{array}{c}-0.042 * * * \\
(0.006)\end{array}$ & $\begin{array}{l}-0.001 \\
(0.008)\end{array}$ & $\begin{array}{c}- \\
0.051^{* * *} \\
(0.007)\end{array}$ & $\begin{array}{c}0.065^{* * *} * \\
(0.014)\end{array}$ & $\begin{array}{c}0.026^{* * * *} \\
(0.009)\end{array}$ & $\begin{array}{c}0.032 * * * \\
(0.008)\end{array}$ & $\begin{array}{c}0.010 \\
(0.011)\end{array}$ \\
\hline Observations & 26,625 & 92,982 & 50,822 & 68,785 & 8,686 & 58,250 & 46,003 & 20,933 \\
\hline R-squared & 0.695 & 0.703 & 0.754 & 0.681 & 0.687 & 0.702 & 0.711 & 0.554 \\
\hline \multicolumn{9}{|c|}{ Panel B - Effect of the refugee coefficient according to the interaction between gender and employment sector } \\
\hline \multirow[b]{3}{*}{$\begin{array}{l}\text { Registered } \\
\text { refugee }\end{array}$} & Female & Male & Female & Male & Female & Male & Female & Male \\
\hline & $\begin{array}{c}\times \\
\text { public } \\
\end{array}$ & $\begin{array}{c}\times \\
\text { public } \\
\end{array}$ & $\begin{array}{c}\times \\
\text { private }\end{array}$ & $\begin{array}{c}\times \\
\text { private } \\
\end{array}$ & $\begin{array}{c}\times \\
\text { public } \\
\end{array}$ & $\begin{array}{c}\times \\
\text { public } \\
\end{array}$ & $\begin{array}{c}\times \\
\text { private } \\
\end{array}$ & $\begin{array}{c}\times \\
\text { private }\end{array}$ \\
\hline & $\begin{array}{c}0.029 * * * \\
(0.010)\end{array}$ & $\begin{array}{l}-0.016 * \\
(0.008)\end{array}$ & $\begin{array}{c}-0.023 \\
(0.018)\end{array}$ & $\begin{array}{c}- \\
0.057 * * * \\
(0.007)\end{array}$ & $\begin{array}{c}0.085 * * * \\
(0.017)\end{array}$ & $\begin{array}{c}0.026 * * * \\
(0.008)\end{array}$ & $\begin{array}{c}0.005 \\
(0.058)\end{array}$ & $\begin{array}{c}0.011 \\
(0.011)\end{array}$ \\
\hline Observations & 14,854 & 35,968 & 11,771 & 57,014 & 7,171 & 38,832 & 1,515 & 19,418 \\
\hline R-squared & 0.726 & 0.771 & 0.648 & 0.691 & 0.678 & 0.723 & 0.496 & 0.573 \\
\hline \multicolumn{9}{|c|}{$\begin{array}{l}\text { Notes: The robust standard errors are in parentheses and clustered at the locality level. The data were collected from the PCBS Labor Force Survey } \\
\text { (1999-2012). All the regressions' specifications are based on wage equations with the regressors gender, experience, experience squared, years of } \\
\text { schooling, marital status, urban area/refugee camp residence, percentage of the locality under area C, whether the locality was affected by the } \\
\text { separation wall, an employment sector dummy, quarter and district fixed effects, and a set of occupational and industry dummies. The analyses do } \\
\text { not include observations of workers who report their place of work as being Israel or Israeli settlements. Significance level: } * * * p<0.01,{ }^{* *} \text { p }<0.05 \text {, } \\
\text { and * }<00.1 \text {. }\end{array}$} \\
\hline
\end{tabular}




\section{CONCLUSION}

In this paper, the wage gap between Palestinian non-refugees and refugees in the West Bank and Gaza over the years 1999-2012 was analyzed. First, the unadjusted wage gap between the two groups over the period of interest was quantified, and findings suggest that the wage differential between the two groups has different directions in the two regions. Second, in exploring whether this change in the wage gap can be attributed to differences in workers' characteristics, regional differences, and occupational choices, findings suggest that part of this change could be attributed to the regional variation between Gaza and the West Bank, employment in Israel, and occupational choices. Third, the Oaxaca-Blinder decomposition was employed to estimate the human capital and unexplained components of the wage gap between 1999 and 2012. In the West Bank, the wage gap has always existed and favored non-refugees. A significant part of this wage gap is explained by the larger portion of non-refugee workers in the Israeli labor market. However, this difference still exists after excluding workers employed in Israel. The wage gap is greater among low-skilled workers and in the private sector; most of this gap among unskilled workers is attributed to the unexplained part of the wage decomposition model. In Gaza, in all the periods the wage gap is in favor of refugees. Among the skilled workers, the endowment effect makes up most of the wage gap until 2006, then most of this wage gap is attributed to the treatment effect - the "unexplained part" - in the following years. The human capital components explain most of the wage differential among unskilled workers over the years 1999-2012. The results of the study indicate the importance of existing policies that encourage the absorption of refugees in the private and public sectors, especially in the West Bank. Investment in education and the expansion of public sector employment contributes to mitigating this wage gap. Palestinian refugees, particularly those who live in refugee camps, are exposed to poverty as well as other adverse life circumstances. The recent threats by the US government to reduce aid to the UNRWA (Hincks 2018) will throw Palestinian refugees' future into doubt and increase their suffering. 


\section{REFERENCES}

Abdul-Hamid, H., H. Patrinos, J. Reyes, J. Kelcey, and A. D. Varela. 2015. Learning in the face of adversity: The UNRWA education program for Palestine refugees. Washington, DC: World Bank Group.

A1 Husseini, J., and R. Bocco. 2009. "The status of the Palestinian refugees in the Near East: The right of return and UNRWA in perspective." Refugee Survey Quarterly 28(2-3): $260-85$.

Altonji, J. G., and C. R. Pierret. 2001. "Employer learning and statistical discrimination." Quarterly Journal of Economics 116(1): 313-50.

Angrist, J. D. 1995. "The economic returns to schooling in the West Bank and Gaza Strip." American Economic Review 85(5): 1065-87.

—. 1998. "The Palestinian labor market between the Gulf War and autonomy." MIT Working Paper 98-5. Cambridge, MA: MIT Department of Economics.

B'Tselem. 2012. "The long term impact of Israel's separation barrier in the West Bank." Technical report. Jerusalem: B'Tselem, The Israeli Information Center for Human Rights in the Occupied Territories.

Benmelech, E., C. Berrebi, and E. F. Klor. 2010. "The economic cost of harboring terrorism." Journal of Conflict Resolution 54(2): 331-53.

Björklund, A., M. Lindahl, and E. Plug. 2006. "The origins of intergenerational associations: Lessons from Swedish adoption data." Quarterly Journal of Economics 121(3): 9991028.

Black, D., A. Haviland, S. Sanders, and L. Taylor. 2006. "Why do minority men earn less? A study of wage differentials among the highly educated." The Review of Economics and Statistics 88(2): 300-13.

Borjas, G. J., and J. C. Van Ours. 2010. Labor Economics. Boston: McGraw-Hill/Irwin.

Calì, M., and S. H. Miaari. 2013. "The labor market impact of mobility restrictions: Evidence from the West Bank.” World Bank Policy Research Working Paper 6457. Washington, DC: World Bank Group.

Daoud, Y. 2005. "Gender gap in returns to schooling in Palestine." Economics of Education Review 24(6): 633-49.

Daoud, Y., and T. Sadeq. 2014. "Return to schooling for males and females in Palestine: Trends and determinants." Working Paper. Ramallah, Palestine: Palestine Economic Policy Research Institute (MAS). 
Daoud, Y., and R. Shanti. 2012. "Wage differentials and employment sector choice for Palestinian men and women: an empirical assessment." Munich Personal RePEc Archive, MPRA Paper No. 39782. Available at: https://mpra.ub.unimuenchen.de/39782/1/MPRA_paper_39782.pdf

. 2016. "Private-public sector employment choice and wage differentials in Palestine: A gender perspective." In N. Chamlou and M. Karshenas (eds.), Women, work and welfare in the Middle East and North Africa: The role of socio-demographics, entrepreneurship and public policies. London and Paris: IC Publishing.

Di Maio, M., and T. K. Nandi. 2013. "The effect of the Israeli-Palestinian conflict on child labor and school attendance in the West Bank." Journal of Development Economics 100(1): 107-16.

Eiland, G. 2010. “The IDF in the Second Intifada.” Strategic Assessment 13(3): 27-37.

Fallah, B. 2016. "Evaluation of the efficiency of the Palestinian labor market." Technical report. Ramallah, Palestine: Palestine Economic Policy Research Institute (MAS).

- 2017. "The effect of public sector on private jobs: Evidence from the occupied West Bank." Economic Research Forum Working Paper No. 1119. Cairo: Economic Research Forum.

Fallah, B., and Y. Daoud. 2015. "Wage differentials and economic restrictions: Evidence from the occupied Palestinian territories." Economics of Peace and Security Journal 10(1): $13-22$.

Gazit, S. 1995. The carrot and the stick: Israel's policy in Judaea and Samaria, 1967-68. Washington, DC: B'nai B'rith Books.

Grodsky, E., and D. Pager. 2001. "The structure of disadvantage: Individual and occupational determinants of the black-white wage gap." American Sociological Review 66(4): 54267.

Heckman, J. 1974. "Shadow prices, market wages, and labor supply." Econometrica: Journal of the Econometric Society 42(4): 679-94.

—. 1979. "Sample selection bias as a specification error." Econometrica 47(1): 153-61.

Hinks, J. 2018. “The U.S. Is Holding Back a Further \$45 Million in Aid for Palestine.” Time, January 19.

Human Rights Watch. 2002. "Jenin: IDF military operations." Technical report. New York: Human Rights Watch. Available at: https://www.hrw.org/reports/2002/israel3/ 
Kaas, L., and C. Manger. 2012. "Ethnic discrimination in Germany's labour market: A field experiment." German Economic Review 13(1): 1-20.

Mansour, H. 2010. "The effects of labor supply shocks on labor market outcomes: Evidence from the Israeli-Palestinian conflict." Labour Economics 17(6): 930-39.

MAS (Palestine Economic Policy Research Institute). 2014. "Labour market and employment policies in Palestine.” Technical report. Ramallah, Palestine: Palestine Economic Policy Research Institute (MAS).

Miaari, S. H. 2009. "The public-private wage differential in the West Bank and Gaza: Before and during the Second Intifada." European University Institute Working Paper, MAX Weber Programme MWP 2009/13. Florence: European University Institute.

Miaari, S. H., and R. M. Sauer. 2011. "The labor market costs of conflict: Closures, foreign workers, and Palestinian employment and earnings." Review of Economics of the Household 9(1): 129-48.

Miaari, S., A. Zussman, and N. Zussman. 2014. "Employment restrictions and political violence in the Israeli-Palestinian conflict." Journal of Economic Behavior and Organization 101: 24-44.

MIFTAH (The Palestinian Initiative for Promotion of Global Dialogue and Democracy). 2003. "The Palestinian Dispossession-Frequently Asked Questions.” Fact sheet. Ramallah, Palestine: The Palestinian Initiative for Promotion of Global Dialogue and Democracy.

Oaxaca, R. 1973. "Male-female wage differentials in urban labor markets." International Economic Review 14(3): 693-709.

O’Neill, J. 2003. “The gender gap in wages, circa 2000.” American Economic Review 93(2): 309-14.

PCBS (Palestinian Central Bureau of Statistics). 2010. "Gender gaps in the West Bank, according to the data of the Population, Housing and Establishment Census, 2007." Technical report. Ramallah, Palestine: Palestinian Central Bureau of Statistics.

- 2015. "On the eve of the International Day of Refugees." Technical report. Ramallah, Palestine: Palestinian Central Bureau of Statistics.

Rizk, R. 2016. "Returns to education: An updated comparison from Arab countries." Economic Research Forum Working Paper No. 986. Cairo: Economic Research Forum.

Sarsour, S., R. Naser, and M. Atallah. 2011. "The economic and social effect of foreign aid in Palestine.” Technical report. Ramallah, Palestine: Palestine Monetary Authority. 
Swed, N. 2014. "Essays on socio-economic consequences of violent conflict in the Middle East.” Doctoral dissertation. Berlin: Humboldt-Universitätzu Berlin, Wirtschaftswissenschaftliche Fakultät. Available at: https://edoc.huberlin.de/bitstream/handle/18452/17579/swed.pdf?sequence $=1$

Tansel, A., and Y. Daoud. 2011. "Comparative essay on returns to education in Palestine and Turkey.” IZA Working Paper No. 5907. Bonn, Germany: Institute for the Study of Labor (IZA).

UNESCO (United Nations Educational, Scientific and Cultural Organization). 2011. "World data on education, 7th edition 2010/11.” Technical report. Paris: United Nations Educational, Scientific and Cultural Organization.

UNSCO (Office of the United Nations Special Coordinator for the Middle East Peace Process). 2014. "Report to the Ad Hoc Liaison Committee New York." Technical Report, September 22. New York: Office of the United Nations Special Coordinator for the Middle East Peace Process. Available at https://unsco.unmissions.org/sites/default/files/un_ahlc_report_sept_2014.pdf

UNRWA (United Nations Relief and Works Agency for Palestine Refugees in the Near East). 2014. "Educational research briefs publication plan." Technical report. Amman, Jordan: United Nations Relief and Works Agency for Palestine Refugees in the Near East. Available at:

https://www.unrwa.org/sites/default/files/research_and_development_unit_research_brie fs_-_2014_english.pdf

— 2017. "The United Nations and Palestinian refugees." Technical report. Amman, Jordan: United Nations Relief and Works Agency for Palestine Refugees in the Near East (UNRWA). Available at: https://www.unrwa.org/userfiles/2010011791015.pdf

Vishwanath, T., B. Blankespoor, F. Calandra, N. Krishnan, M. Mahadevan, and M. Yoshida. 2014. "Seeing believes: Poverty in the Palestinian territories." Technical report. Washington, DC: World Bank Group. 


\section{APPENDIX}

Figure A1.a: Share of Palestinian Non-refugee Workers across Various Employment Sectors in the West Bank, 1999-2012

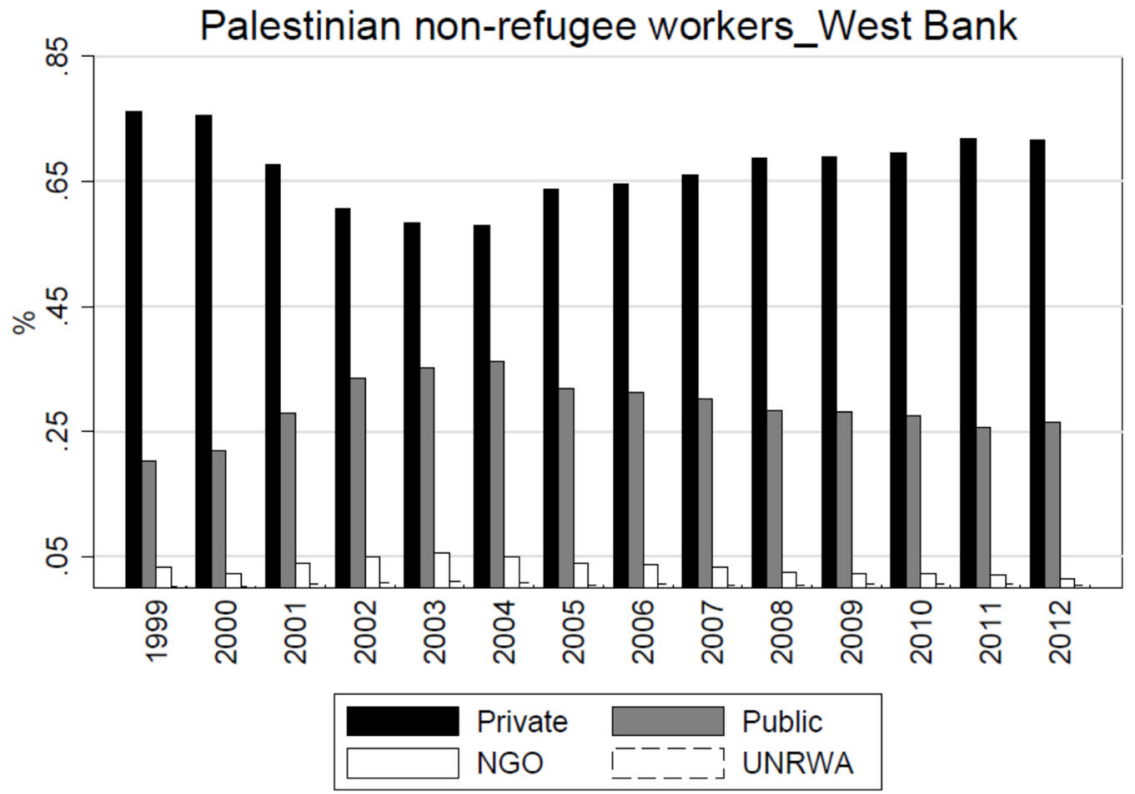

Source: Own calculations based on PCBS data.

Figure A1.b: Share of Palestinian Refugee Workers across Various Employment Sectors in the West Bank, 1999-2012

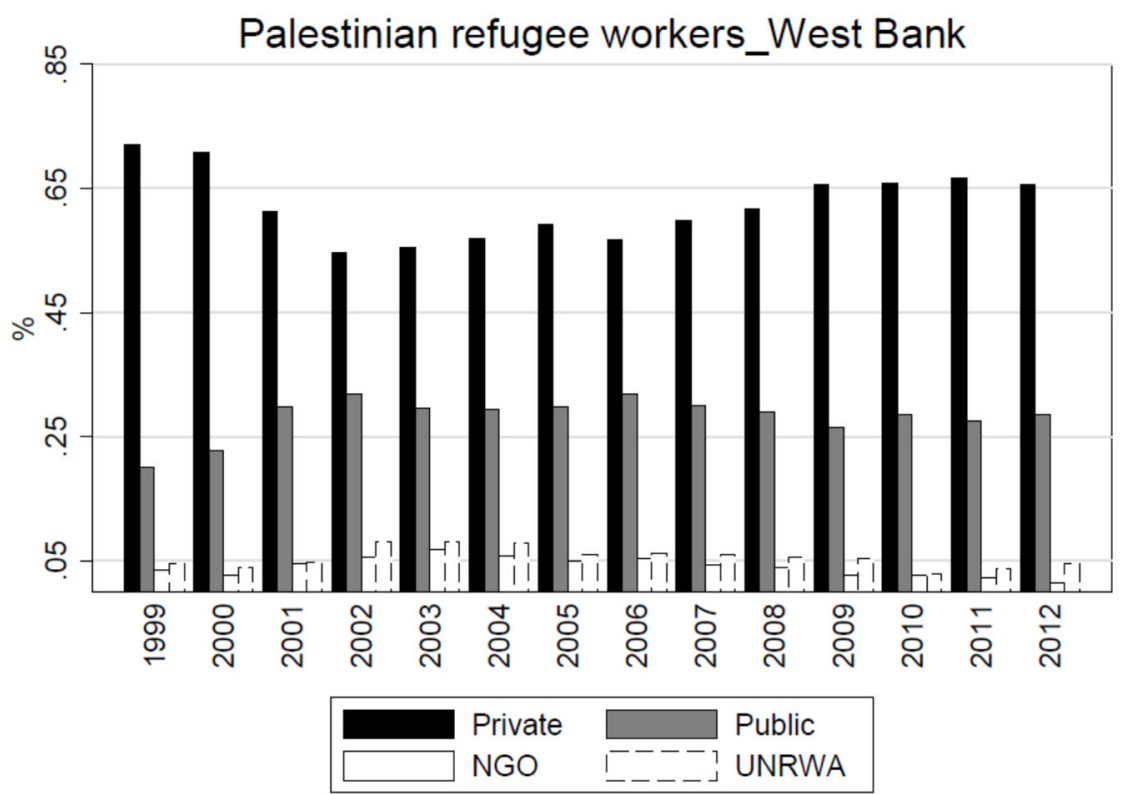

Source: Own calculations based on PCBS data. 
Figure A2.a: Share of Palestinian Non-refugee Workers across Various Employment Sectors in Gaza, 1999-2012

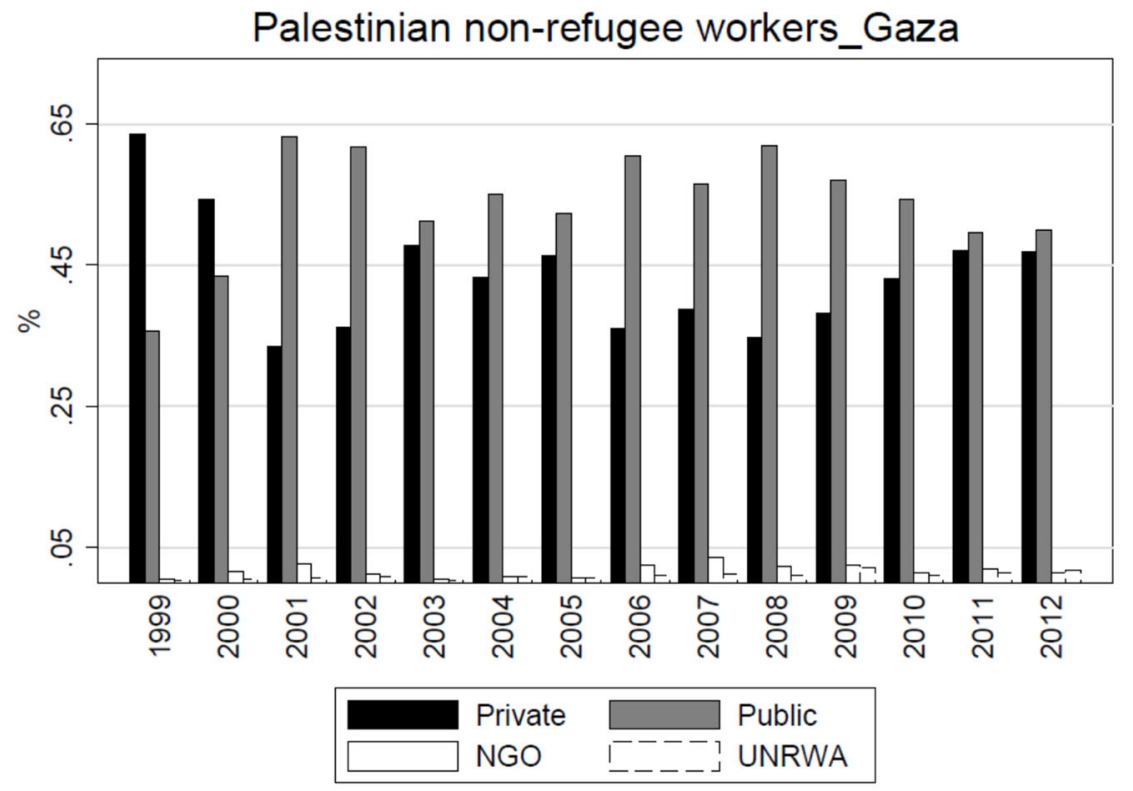

Source: Own calculations based on PCBS data.

Figure A2.b: Share of Palestinian Refugee Workers across Various Employment Sectors in Gaza, 1999-2012

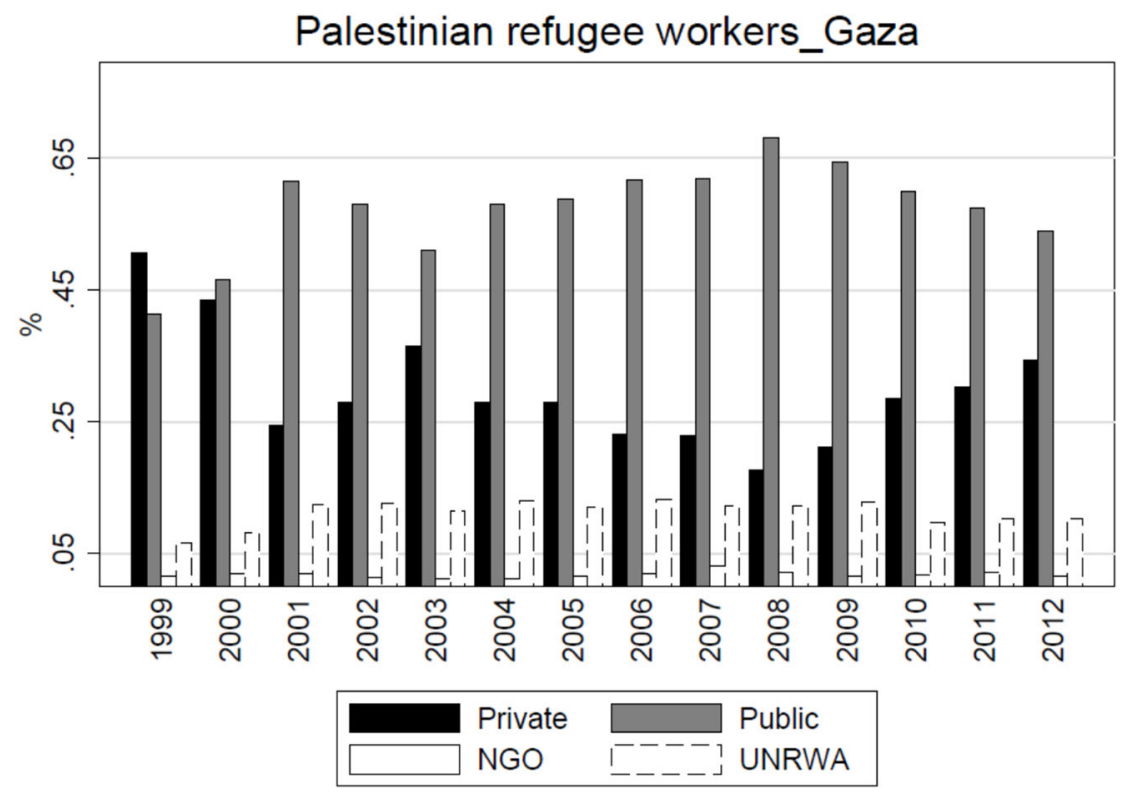

Source: Own calculations based on PCBS data. 
Figure A3: West Bank-Gaza Wage Gap Decomposition by Gender over the Period 19992012

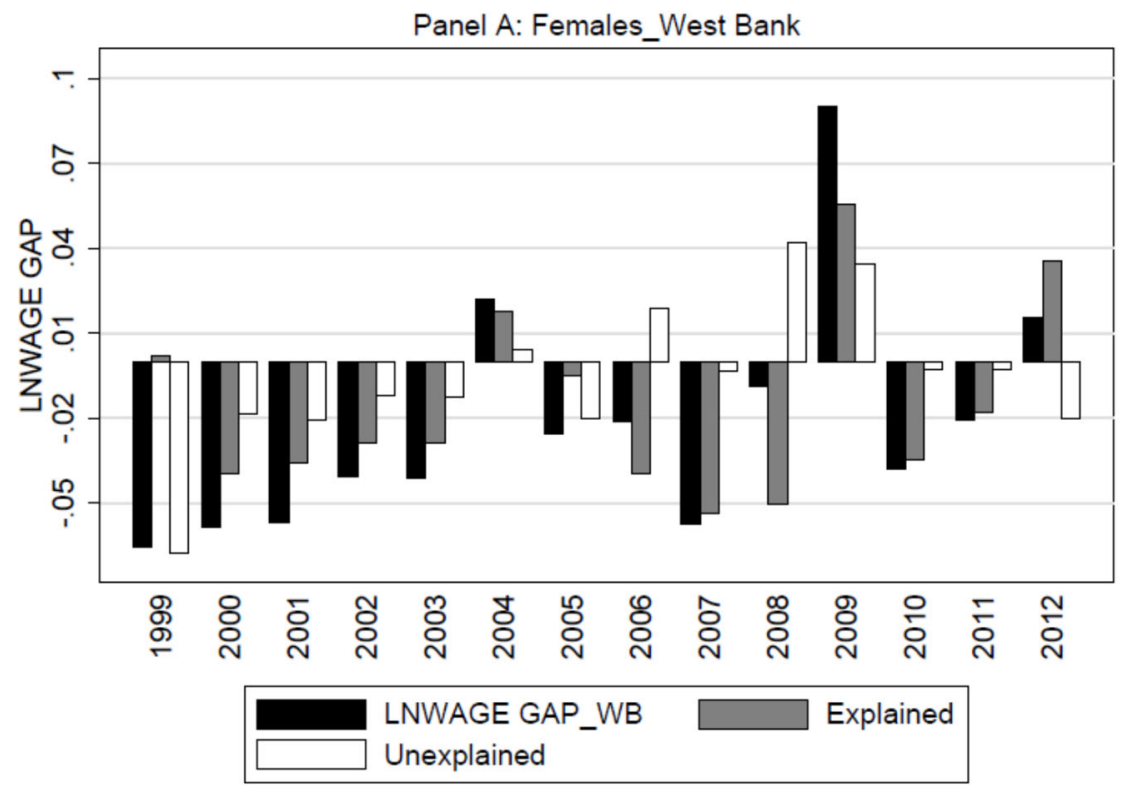

Notes: The analyses do not include observations of workers who report that their place of work is Israel or Israeli settlements. Number of observations: 26,629.Wage gap=Non-refugees' LNWAGE -refugees' LNWAGE

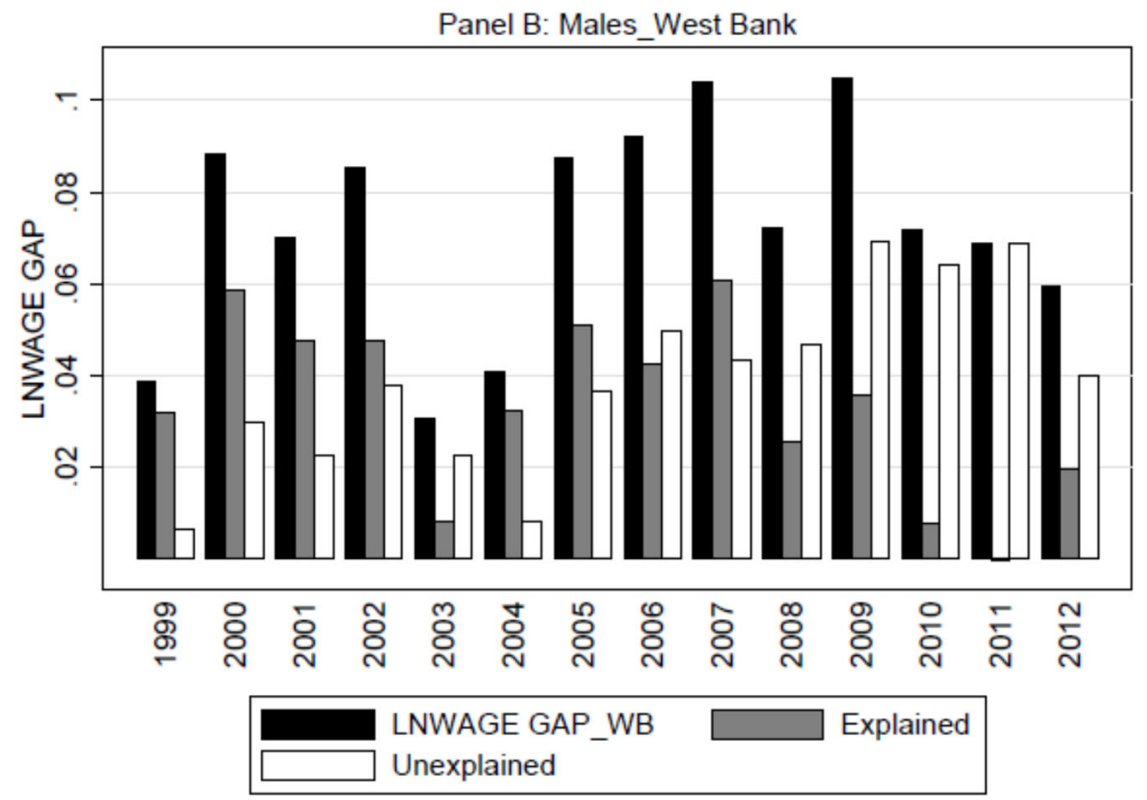

Notes: The analyses do not include observations of workers who report that their place of work is Israel or Israeli settlements. Number of observations: 92,102 .

Source: Own calculations based on PCBS data. 
Figure A4: Gaza Wage Gap Decomposition by Gender over the Period 1999-2012

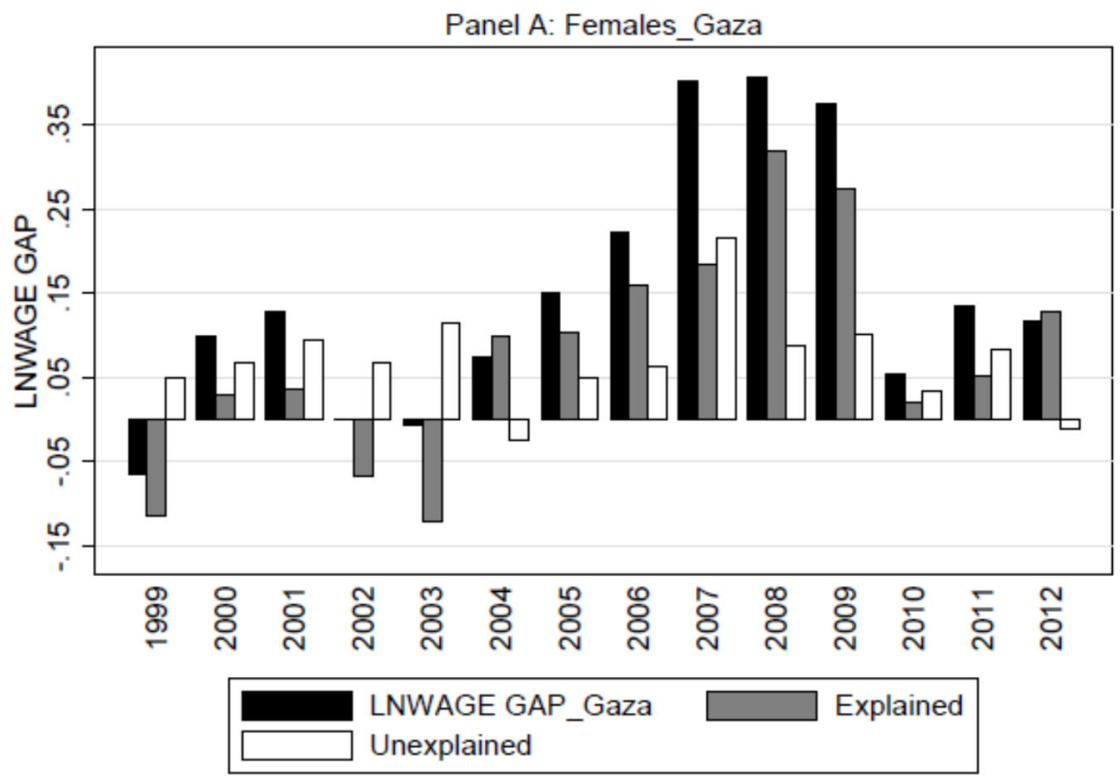

Notes: The analyses do not include observations of workers who report that their place of work is Israel or Israeli settlements. Number of observations: 8,686. Wage gap=refugees' LNWAGE -non-refugees' LWAGE”

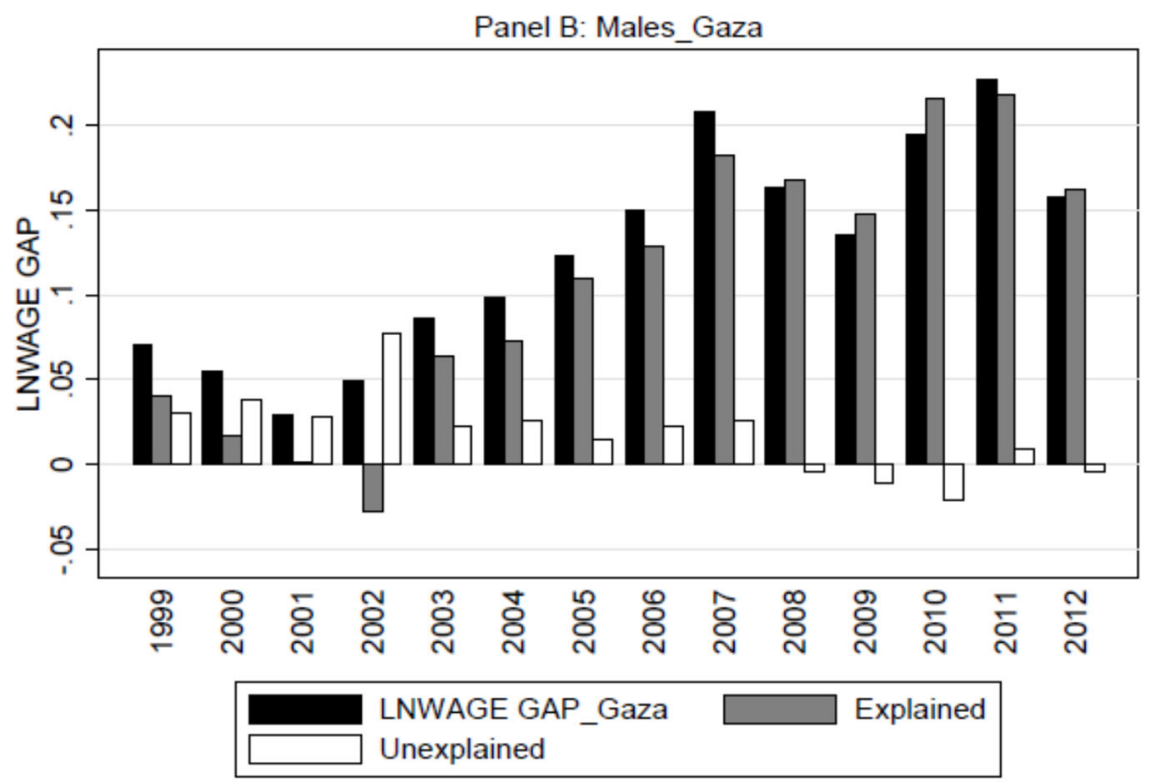

Notes: The analyses do not include observations of workers who report that their place of work is Israel or Israeli settlements. Number of observations: 58,250.

Source: Own calculations based on PCBS data. 
Figure A5.a: Wage Decomposition for Selected Variables in the West Bank

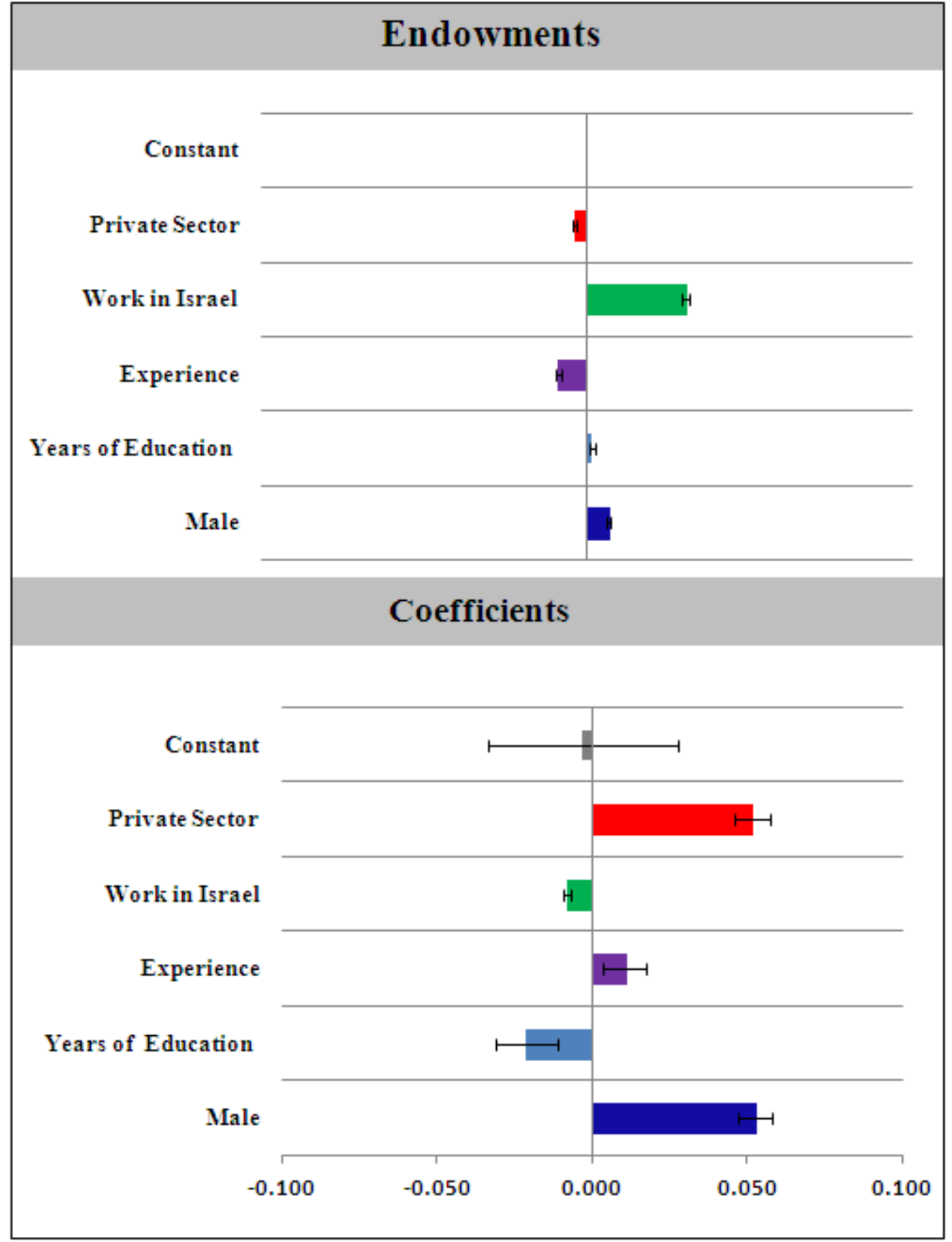

Source: Own calculations based on PCBS data.

Note: The wage gap represents the differences between non-refugees' and refugees' LNWAGE 
Figure A5.b: Wage Decomposition for Selected Variables in Gaza

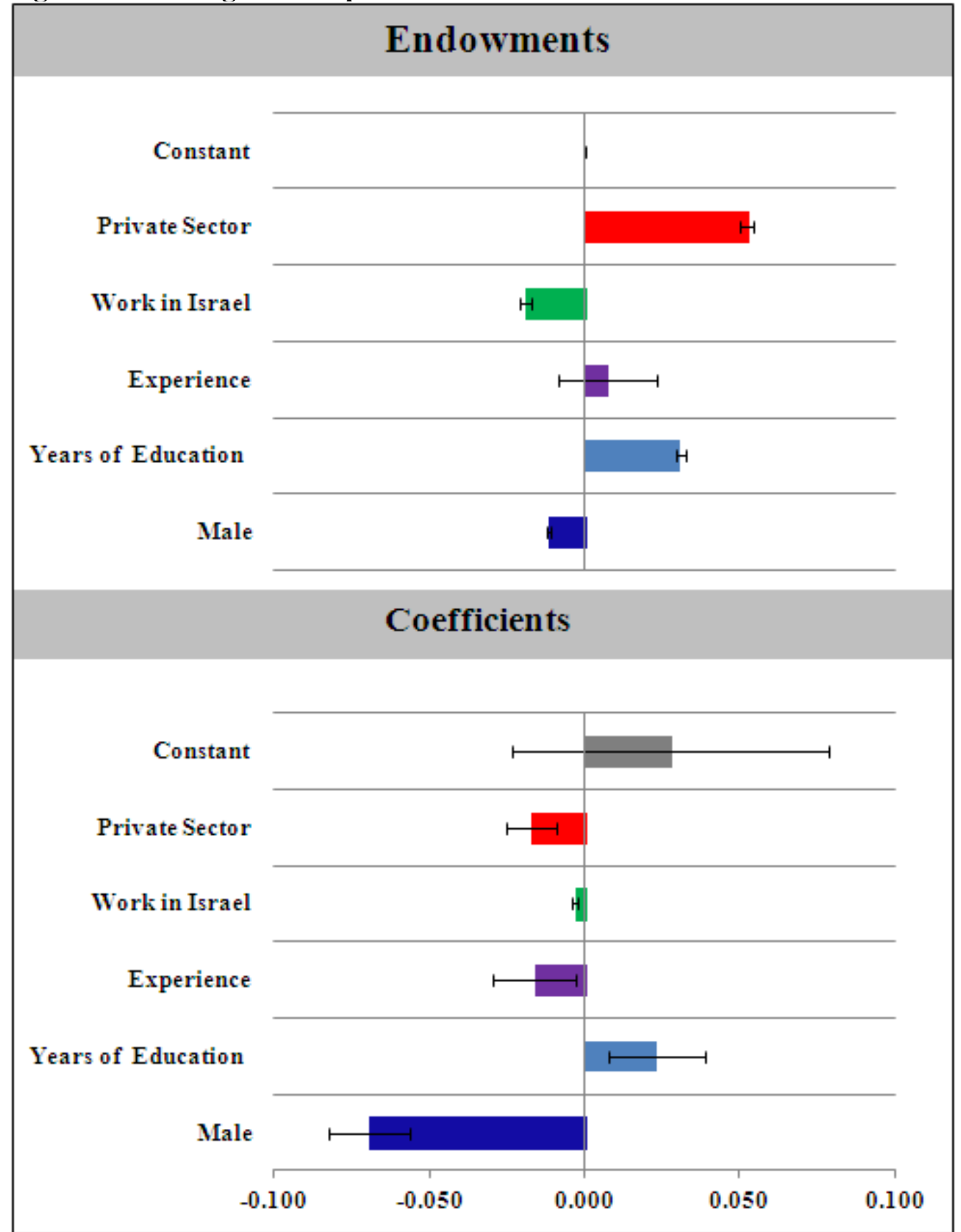

Source: Own calculations based on PCBS data.

Note: The wage gap represents the differences between refugees' and non-refugees' LNWAGE 
Figure A6.a: Share of Palestinian Non-refugee and Refugee Workers in the West Bank Employed in Israel, 1999-2012

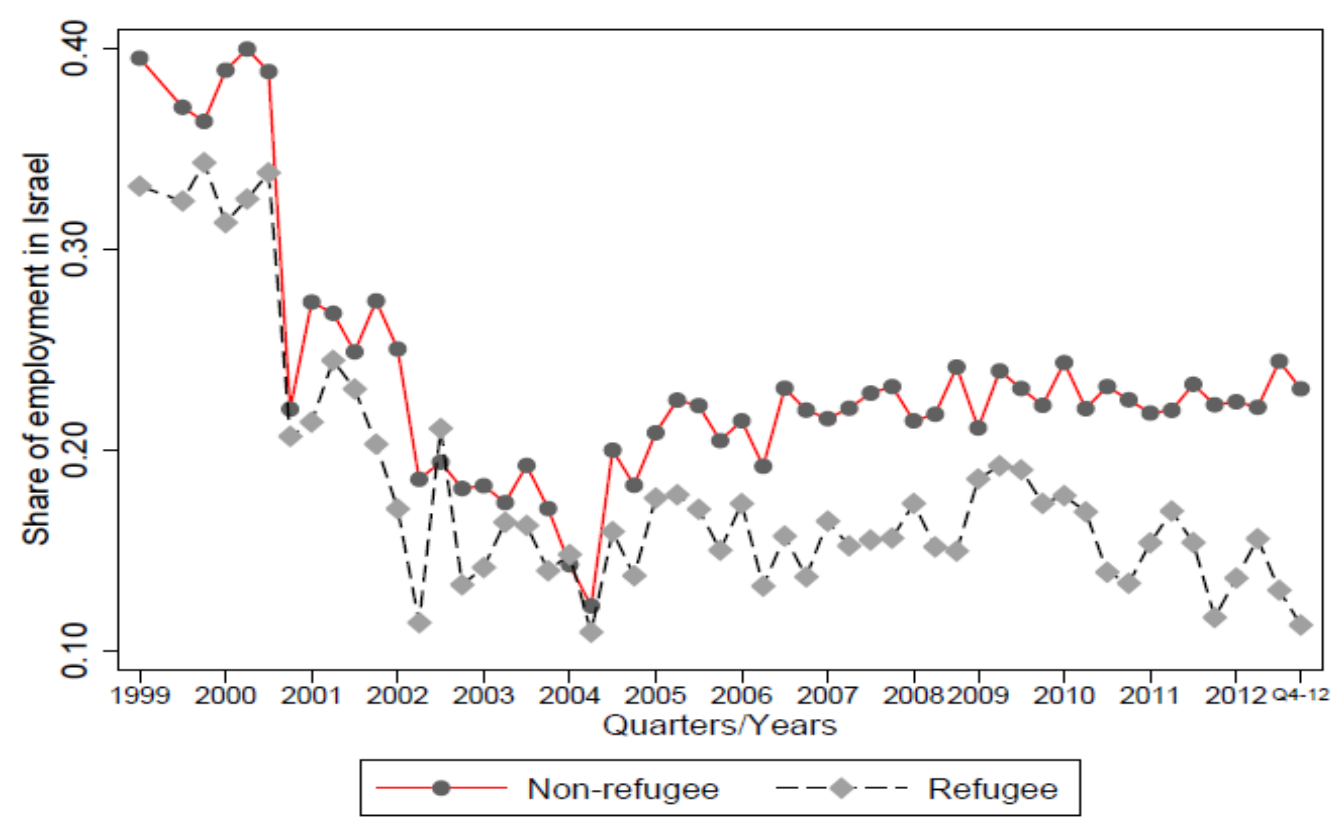

Source: Own calculations based on PCBS data.

Figure A6.b: Share of Palestinian Non-refugee and Refugee Workers in Gaza Employed in Israel, 1999-2012

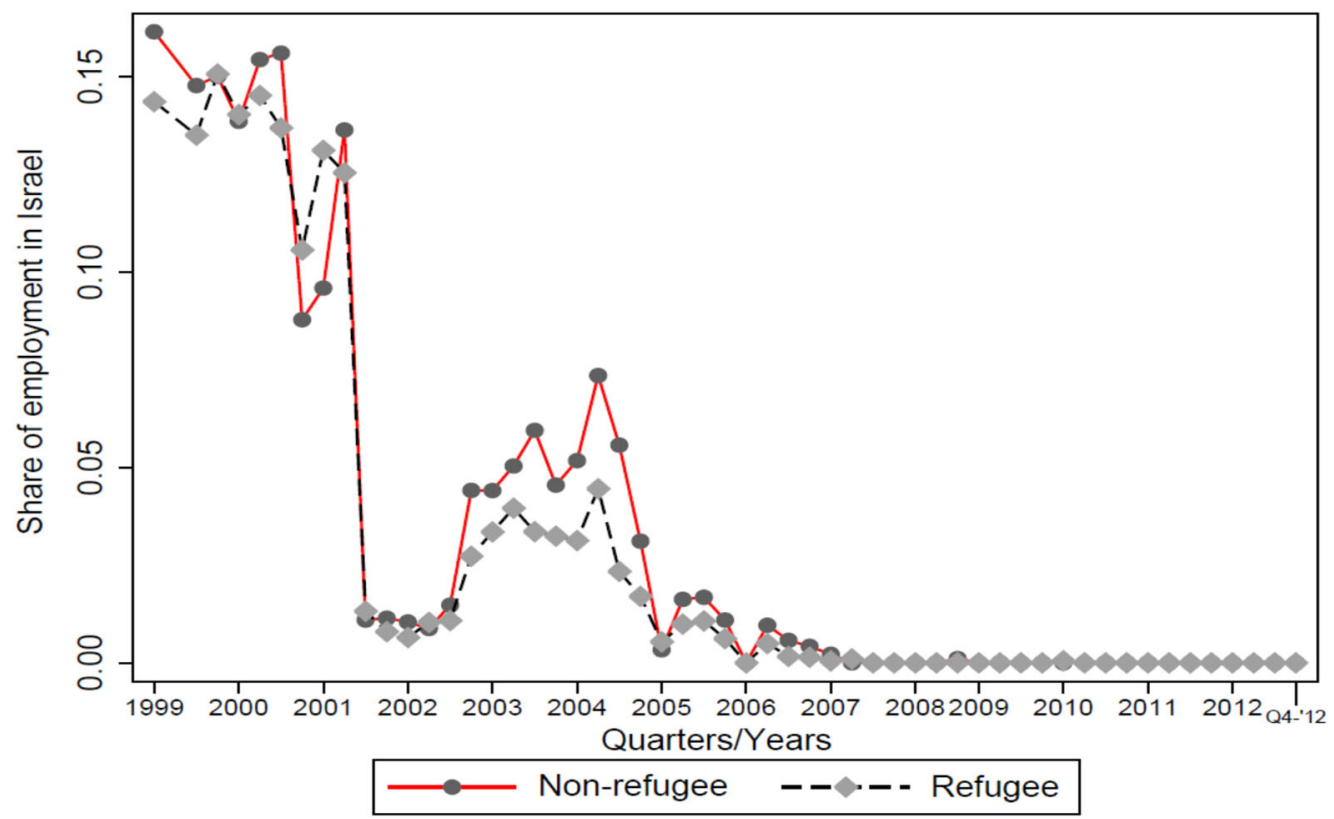

Source: Own calculations based on PCBS data. 